\title{
An Evaluation of Project Risk Dynamics in Sino-Africa Public Infrastructure Delivery; A Causal Loop and Interpretive Structural Modelling Approach (ISM-CLD)
}

\author{
Bridget Tawiah Badu Eshun *(D) and Albert P.C. Chan (D) \\ Department of Building and Real Estate, The Hong Kong Polytechnic University, Hong Kong, China; \\ albert.chan@polyu.edu.hk \\ * Correspondence: beshun44@gmail.com or bridget.eshun@connect.polyu.hk
}

check for updates

Citation: Eshun, B.T.B.; Chan, A.P.C. An Evaluation of Project Risk Dynamics in Sino-Africa Public Infrastructure Delivery; A Causal Loop and Interpretive Structural Modelling Approach (ISM-CLD). Sustainability 2021, 13, 10822. https:// doi.org/10.3390/su131910822

Academic Editor: Konstantinos Kirytopoulos

Received: 30 August 2021

Accepted: 22 September 2021

Published: 29 September 2021

Publisher's Note: MDPI stays neutral with regard to jurisdictional claims in published maps and institutional affiliations.

Copyright: (c) 2021 by the authors. Licensee MDPI, Basel, Switzerland. This article is an open access article distributed under the terms and conditions of the Creative Commons Attribution (CC BY) license (https:/ / creativecommons.org/licenses/by/ $4.0 /)$.
Abstract: Africa's growth in public infrastructure provision has been fueled by the collective effort of the government authority and foreign private investors. China, through state-owned corporations, has become one of the leading infrastructure financier springing up numerous projects in transport, energy, oil and gas, water, and sewage sectors in Africa. Infrastructure procurement in developing countries comes with complexities and uncertainties. While Sino-Africa transnational public-private partnerships (TPPP) are becoming an increasingly popular route for public infrastructure procurement, their specific project risks and dynamics are not yet fully understood due to the typical assessment of risk autonomously. This paper identifies pertinent project risks in Sino-Africa TPPPs and applies system thinking in evaluating their behaviour and dynamics. An extensive review of literature and expert opinion employing semi-structured interviews was adopted in the identification and assessment of risk factors. Additionally, the study applied causal loop and interpretive structural modelling as an integrated approach in the assessment of risk behaviour from a systems perspective. Results indicate that risk factors associated with Sino-Africa TPPPs are interactive and portray curious systemic behaviour. Risk factors like force majeure and others associated with the governance structure and stability of the host African country are most influential, and their occurrence could inhibit project success. The study recommends that in conjunction with the conventional risk assessment by impact, systems thinking can be adopted to evaluate and comprehend the dynamics and interactions amongst the risk factors. This will improve risk assessment efficiency and fair allocation and treatment of risks as a conduit for project success and promote a win-win partnership for project actors.

Keywords: transnational public-private partnership; Sino-Africa; risk assessment; systems thinking; causal loop diagram; interpretive structural modelling

\section{Introduction}

Infrastructure development is a critical catalyst to the quest for sustainable development in Africa. Most regions in Africa have gradually seen improvement in infrastructure attributable to the availability of foreign direct investments (FDIs) [1]. China is currently a major foreign investor in Africa's infrastructure [2]. The Sino approach typically combines the provision of financial and technical aid through state-owned corporations in partnership with African government authorities, depicting a unique transnational public-private partnership (TPPP). Ref. [3], captured TPPPs as the collective involvement of non-state (transboundary) actors in the provision of public goods or services which are primarily the sole mandate of the state actors or government. This has been capitalised by most African countries as a unique arrangement through which public infrastructure is delivered [4]. Development sectors include transport, housing, oil and gas, water and sewage, information communication technology, mining, and energy [5]. The feat of public infrastructure provision in Africa is reliant on efficiency in managing risks due to socio-economic and 
political dynamics in the region [6]. Furthermore, the involvement of foreign corporations creates a partnership that is pivoted on the achievement of win-win arrangements [7], and one way is to ensure fair and efficient treatment and sharing of risks between these corporations (private actors) and the African government authority (public actor) [8].

Risk management (RM) is critical in the life cycle development of public infrastructure when delivered through non-state actors or private sector engagement like TPPP [9]. The poor management of risks has caused the failure of most infrastructure projects in developing countries [10]. TPPPs for public infrastructures are well known for the provision of basic facilities for livelihood and therefore considered as projects of high complexity. The influence and consequence of risks are much higher and detrimental in this setting, [11]. Complexity with these infrastructure projects is associated with large-scale works, long duration, and high investment. Moreover, the multistakeholder nature of these partnerships makes the handling and allocation of risks very intricate as compared to the traditional procurement practice [12]. The above project features make it difficult to manage risks effectively to achieve project success [13]. In developing countries, risk events in public infrastructure procurements are dynamic and occur at different stages of development [14]. Studies on Chinese infrastructure investments in Africa have reiterated the criticality of assessing and devising efficient strategies to manage the risk components of the projects $[15,16]$. The study of [17] further illustrated the dire effect of risk events on these arrangements sampling the Congo Siciomines project which has become less lucrative, and hence unsuccessful. Effective RM is, therefore, necessary for the successful implementation of Sino-Africa TPPPs. Risk management systematically entails the identification, assessment, allocation, and treatment or mitigation. Although studies have well established the cruciality and have focused on various aspects, limited attention and efforts have been put in probing the overall dynamics of infrastructure project risks. The assessment of risk interactions and how it affects the successful life cycle development of the project is overlooked [18].

Meanwhile, project risks in public infrastructure provision are interrelated and this questions the fundamental logic to typical project risk management, treating risks as independent [13]. This could project a wrong estimation of risk impact and can pose a limitation on the effectiveness of risk-sharing and treatment strategies adopted by project actors. Therefore, it is vital to consider dynamic interactions between project risks when assessing them. The concept of systems thinking can be applied in analysing the interrelationships between risk factors to facilitate better management and decision making [19]. The application of systems thinking in public infrastructure delivery through private sector involvement has gained much focus in recent times. There is maturing literature in system thinking in areas such as productivity, construction waste, and safety; however, exploration in risk management is comparatively limited [20].

In the field of systems thinking, the causal loop diagram (CLD) is a feedback enabling tool for critical analysis of complex problems [21]. A couple of risk management studies have adopted CLDs for risk evaluation [22-24]. Additionally, the interpretive structural modeling (ISM) also begets a structural and relationship analysis from the systems viewpoint and have also been adopted in risk management studies [25-27]. The robustness of dynamic systems evaluation is improved through the integration of these tools and has been adopted in recent risk evaluation studies [28,29]. The CLDs enable a better interpretation of the dynamics, while the ISM process establishes the relationships and dimensional order amongst the variables which enable prioritisation decisions. Given the criticality of systems thinking in risk assessment and the unique nature of Sino-Africa TPPPs, this study evaluates risk factors pertinent to the life cycle development of public infrastructure projects in Africa using the ISM-CLD approach. This project allows a better appreciation of risk behaviour for proper treatment, allocation, and control strategies towards the realisation of a win-win arrangement for both parties. 


\section{Literature Review}

\subsection{Sino-Africa Infrastructure Partnerships}

The involvement of non-state actors (private sector) in the provision of public infrastructure has become a globally accepted and practiced procurement route. Public-private partnership is a collaboration between private sector corporations and public authorities for the direct provision of public goods or services through the combination of public sector oversight and private sector resources and expertise [30]. PPP has many forms and scales, usually established over design, financing, construction, tenure, operations, control, and handover modes [31]. According to [32], public-private partnerships have gained popularity in Africa and most of these partnerships involve foreign investors, i.e., Transnational PPPs (TPPPs). China has steadily combined the provision of financial and technical aid for the construction of infrastructure in most African countries with business pursuits and interests $[7,33]$. Unique to this type of partnership is the use of state-owned corporations who come in as private sector investors [34,35], which makes a distinctive representation of Transnational PPPs [36]. These partnerships also place much concern on the sharing of risks between the Chinese corporations and the African contracting authority in the implementation of public infrastructure. This is geared towards the success of the project and the promotion of win-win partnership and corporation ties between project actors [37].

\subsection{Risk Management in Public Infrastructure Provision}

The impact of risks on the successful completion of PPP projects cannot be underestimated [38]. Risk management follows a process of identification, assessment, allocation, and control tactics. Project actors desire to obtain a win-win partnership and this is dependent on the assessment and allocation of project risks [8]. Although risk sharing is the most significant aspect of the risk management process in PPPs, a poor assessment of risk factors could affect the fairness and efficiency in the allocation and eventually lead to project failure [39]. Studies in transnational PPPs also affirm that risks are assessed to determine the most efficient allocation and mitigation strategies [40,41]. Table 1 summarises risk factors in public infrastructure provision.

Table 1. Risk factors in PPPs.

\begin{tabular}{|c|c|c|c|c|c|c|c|c|c|c|c|c|c|c|c|c|}
\hline ID & Risk Factors & A & B & $\mathrm{C}$ & $\mathbf{D}$ & E & F & G & $\mathbf{H}$ & I & $\mathbf{J}$ & $\mathbf{K}$ & $\mathbf{L}$ & $\mathbf{M}$ & $\mathbf{N}$ & $\mathrm{O}$ \\
\hline $\mathrm{R} 1$ & Bribery and corruption & * & & * & & & * & & * & & & & & * & * & \\
\hline $\mathrm{R} 2$ & $\begin{array}{l}\text { Government or Political } \\
\text { Instability }\end{array}$ & * & & $*$ & & & & * & $*$ & & * & & & * & * & \\
\hline R3 & $\begin{array}{l}\text { Weak regulatory framework and } \\
\text { policy monitoring }\end{array}$ & $*$ & & & & & & * & & & & & $*$ & * & & * \\
\hline $\mathrm{R} 4$ & Project Cost overrun & * & * & $*$ & & & * & & $*$ & * & * & & $*$ & $*$ & * & * \\
\hline R5 & Public opposition to the project & * & * & * & * & & * & & * & & * & * & $*$ & & * & \\
\hline R6 & $\begin{array}{l}\text { Unfavourable host country } \\
\text { economy }\end{array}$ & & & & $*$ & & & & * & & * & & $*$ & & & \\
\hline R7 & $\begin{array}{l}\text { Inadequate or lengthy } \\
\text { negotiation }\end{array}$ & * & $*$ & & $*$ & & & & & * & & & & * & & \\
\hline $\mathrm{R} 8$ & $\begin{array}{l}\text { High cost of operation and } \\
\text { maintenance }\end{array}$ & * & & & & & * & & * & & * & & $*$ & * & * & * \\
\hline R9 & $\begin{array}{c}\text { Poor/lengthy public } \\
\text { decision-making process }\end{array}$ & & * & * & & * & & & & & & * & & * & * & \\
\hline R10 & $\begin{array}{c}\text { Expropriation and } \\
\text { nationalization of assets }\end{array}$ & $*$ & & $*$ & & * & * & & & * & * & & & & & \\
\hline $\mathrm{R} 11$ & Legal and regulatory changes & * & & * & & & & & * & * & & $*$ & * & * & * & \\
\hline
\end{tabular}


Table 1. Cont.

\begin{tabular}{|c|c|c|c|c|c|c|c|c|c|c|c|c|c|c|c|c|}
\hline ID & Risk Factors & A & B & $\mathrm{C}$ & $\mathrm{D}$ & $\mathrm{E}$ & $\mathbf{F}$ & G & $\mathbf{H}$ & I & $\mathbf{J}$ & $\mathbf{K}$ & $\mathbf{L}$ & $\mathbf{M}$ & $\mathbf{N}$ & $\mathrm{O}$ \\
\hline $\mathrm{R} 12$ & Force Majeure Risk & * & $*$ & * & & & $*$ & & & * & & * & $*$ & * & * & \\
\hline R13 & Foreign exchange risks & * & & * & & & * & & & $*$ & $*$ & & & * & * & * \\
\hline R14 & $\begin{array}{l}\text { Poor contract design and } \\
\text { management }\end{array}$ & * & $*$ & * & & & & * & & & $*$ & & & & $*$ & \\
\hline R15 & $\begin{array}{c}\text { The inability of the } \\
\text { concessionaire }\end{array}$ & & $*$ & & & $*$ & & & & & * & & & & & \\
\hline R16 & Poor project feasibility studies & & $*$ & & & & & & & & & & & & & \\
\hline $\mathrm{R} 17$ & $\begin{array}{l}\text { Unproven engineering } \\
\text { techniques }\end{array}$ & * & & & * & & $*$ & & & & * & & $*$ & & & \\
\hline R18 & $\begin{array}{l}\text { Cultural and communication } \\
\text { risk }\end{array}$ & * & & * & & & & & & & & & & * & & \\
\hline R19 & High project finance & * & & & * & & & $*$ & $*$ & * & $*$ & $*$ & $*$ & * & * & \\
\hline $\mathrm{R} 20$ & Delayed project Schedule & * & $*$ & * & * & & * & & & * & & & $*$ & * & * & \\
\hline R21 & $\begin{array}{l}\text { Dispute between project's } \\
\text { participants }\end{array}$ & * & & $*$ & & & & & & & & & $*$ & * & $*$ & \\
\hline R22 & $\begin{array}{l}\text { Obsolete technology, Change in } \\
\text { technology }\end{array}$ & * & $*$ & * & & & & & & & & & & & $*$ & * \\
\hline R23 & $\begin{array}{c}\text { Inadequate supporting } \\
\text { infrastructure }\end{array}$ & & $*$ & $*$ & & & & & & & & & $*$ & & $*$ & \\
\hline $\mathrm{R} 24$ & Trade restrictions & & $*$ & & & & & & * & & & & & & & \\
\hline R25 & $\begin{array}{l}\text { Project performance and Quality } \\
\text { risk }\end{array}$ & * & $*$ & & $*$ & & & & & & * & & $*$ & & & \\
\hline $\mathrm{R} 26$ & Inadequate PPP/PFI experience & * & $*$ & & & & & & & & & & $*$ & & & \\
\hline R27 & $\begin{array}{l}\text { Poor sharing of risk and } \\
\text { responsibilities }\end{array}$ & * & & & & & & & & & & & $*$ & & & \\
\hline $\mathrm{R} 28$ & Weather conditions & * & & $*$ & & * & & & & & & & $*$ & & & \\
\hline R29 & $\begin{array}{c}\text { Poor workmanship quality and } \\
\text { standards }\end{array}$ & * & & & $*$ & & & & * & & & & & & $*$ & \\
\hline R30 & Market demand changes & & $*$ & $*$ & $*$ & & $*$ & & * & $*$ & $*$ & * & $*$ & * & * & \\
\hline R31 & Delay in financial closure & * & & & & & & & & & & & & & & $*$ \\
\hline R32 & Environmental risks & $*$ & $*$ & & $*$ & & & & * & & & & $*$ & * & & * \\
\hline R33 & Land acquisition & * & & * & * & * & & & & * & * & * & $*$ & & * & * \\
\hline
\end{tabular}

* references [14,32,36,39,40,42-51] Key: A = Babatunde et al. (2019), B = Chou and Pramudawardhani (2015), C = Ameyaw and Chan (2015); $\mathrm{D}=$ Nguyen et al. (2018), E = Abednego \& Ogunlana (2006), F = Rebeiz (2012), G = Choi (2010) H = Ahmad et al. (2018), I = Wibowo \& Mohamed (2010), J = Alireza et al. (2014), K = Mazher et al. (2018), L = Almarri et al. (2019), M = Yu et al. (2018), N = Osei-Kyei and Chan (2017), O = Ibrahim et al. (2006).

\subsection{Systems Thinking in Risk Management}

Risk management requires an interdisciplinary and adaptable method that allows capturing the changing behaviours of risks including the explanation of processes involved in the management of infrastructure construction [52].

Owing to the complex nature of PPP implementation, it is prudent to emphasise that risks events are not only numerous but have interaction among each other and the adoption of systems thinking enables feedback and structural analysis to simulate mitigation policies before development. Some classical risk management studies applied system dynamics in the development of risk classification systems and assessments from network simulations which enabled insight into risks without losing operational or practical advantages $[53,54]$. Comparatively, the application of system dynamics for problem-solving 
in PPP/PFI projects is small but has been rising over the past few years in risk assessment $[55,56]$, based on a case study, adopted a qualitative application and developed a causal relationship diagram that features most risk factors including cost, environmental, design, schedule, construction, and quality risk factors. The study by [57] on the assessment of demand risk dynamics for toll road projects used a system dynamics method. Other studies also incorporated other analytical tools for the assessment of risks. For example, Ref. [58] developed an integrated fuzzy system dynamic (FSD) as a quantitative risk management approach. In addition, Ref. [59] assessed the dynamics of project risk complexities concerning design and construction in megaprojects using SDANP, an innovative combination of Analytical Network Process (ANP) and system dynamics (SD). More recently, other studies in risk assessment integrate methods that pedigree from systems thinking. For instance, Ref. [29] innovatively combined the interpretive structural modeling and system dynamics as an SD-ISM approach to assess and determine the dynamics of construction project risks in the design stage.

\section{Research Methodology}

The unique nature of Sino-African public infrastructure dealings propelled an interpretative approach to decipher its associated risk ecosystem. The study adopted systems thinking in the assessment of risk factors identified. Systems thinking deals with assessing issues or a problem as systemic wholes and provides a language for communicating dynamic complexities and interdependencies [60]. It emphasises that any problem or phenomenon directly or indirectly forms part of a bigger domain. Systems are constructs used for engaging with and improving situations of real-world complexities [61]. Systems thinking (ST) is applied exploratorily to understand the dynamic behaviour of risks in TPPPs. System thinking presents an integrated view of phenomena and eliminated the traditional view of problems in isolation. Through the development of a qualitative conceptual model coupled with a quantitative simulation, systems thinking determines the nonlinear behaviour and structure among variables, [62]. This paper is, however, focused on qualitatively developing and translating the systemic behaviour and structure of pertinent risk factors in Sino-African public infrastructure implementation. The study adopted a three-stage approach which includes a comprehensive review of literature, semi-structured expert interviews, and the development of the integrated causal loop and interpretive structural modelling approach. Figure 1 summarises the steps which are further elaborated in the ensuing sections.

\subsection{Interpretive Structural Modelling (ISM)}

Interpretive structural modelling is an effective tool that reveals the structure and hierarchical relationships between variables from a systems viewpoint. It was developed to create a systematic problem-solving approach to complex issues [63]. ISM involves measurement on ordinal scales and thus provides a modelling approach that permits qualitative elements to be retained as a vital part of the model. More so, it differs significantly from many conventional approaches that use only quantifiable variables [64]. The ISM provides a method by which order can be enacted on the complexity of variables [65], therefore decisions on risk prioritisation can also be made based on the hierarchical patterns developed. Furthermore, the MICMAC analysis is included in the ISM process to further describe the attributes and behaviours of the risk factors in the system. It is developed from the driving and dependency powers of the risk factors and categorises them into independent, autonomous, linkage, and dependent risks. Several studies incorporate the MICMAC analysis in ISM application [66-68]. 


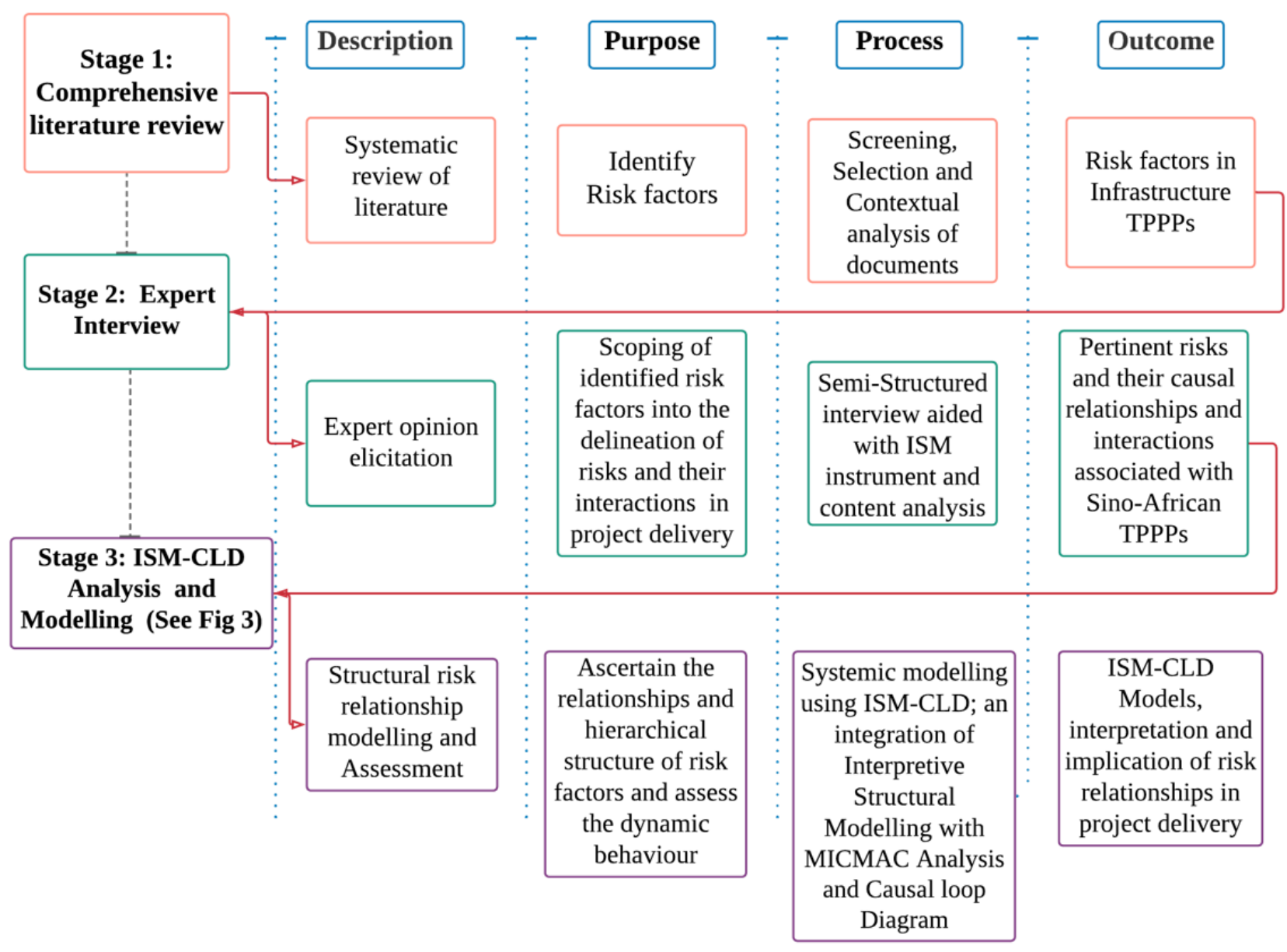

Figure 1. Summary of Methodology.

\subsection{Causal Loop Diagram (CLD)}

To comprehend the dynamics of the risk factors, the causal loop diagram is adopted to describe the circular cause and effect relationships amongst them. This tool uncovers feedback structures and is typical for providing explicit conceptualisation in system dynamics which can be further analysed quantitatively [69]. CLDs define how the distinct elements in a system interact due to the influence of each specific element. The elements in the diagram are linked together by arrows describing which direction the connection is heading. These arrows may have positive or negative indicators, where a positive from one variable to another indicates a cause and effect in that regard, and a negative depicts a cause and effect in the opposite direction. These connecting arrows create feedback loops which could be described as balancing (B) or reinforcing (R) loops. The continuous upsurge in actions within the system is indicated by the R loop, while the B loop acts to introduce stability by reducing changes [70]. Figure 2 depicts an example of a typical CLD.

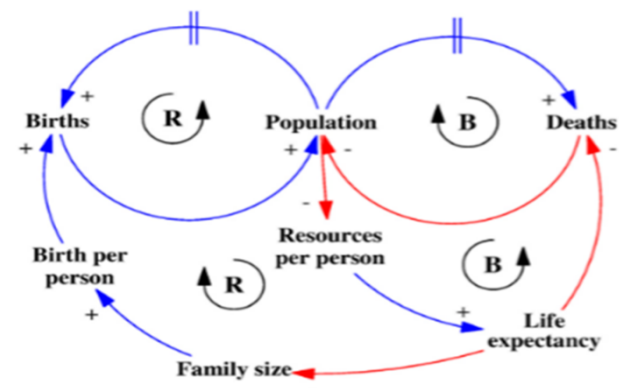

Figure 2. Example of B and R loop in CLDs. Source: Roubík et al., 2020 [69]. 


\subsection{The ISM-CLD Approach}

The integration of the interpretive structural modelling and the Causal loop diagram adequately enables system thinking in risk assessment as the ISM-CLD draws out the nonlinear, structural, and hierarchical relationships amongst the risk factors. The development of CLDs involves problem articulation and the building of a dynamic hypothesis. The ISM produces the hierarchical structure and relationships which instigates prioritisation. Furthermore, the approach in this study provides feed-in data based on expert opinion which replaces the process of inductively generating structural relationships typical in CLDs. The authors of [29] applied a similar method and determined the dynamics in design stage construction project risks using the SD-ISM approach. This approach builds a fortified systemigrams and assessment method. Figure 3 illustrates the workflow of the hybrid method applied in this study.

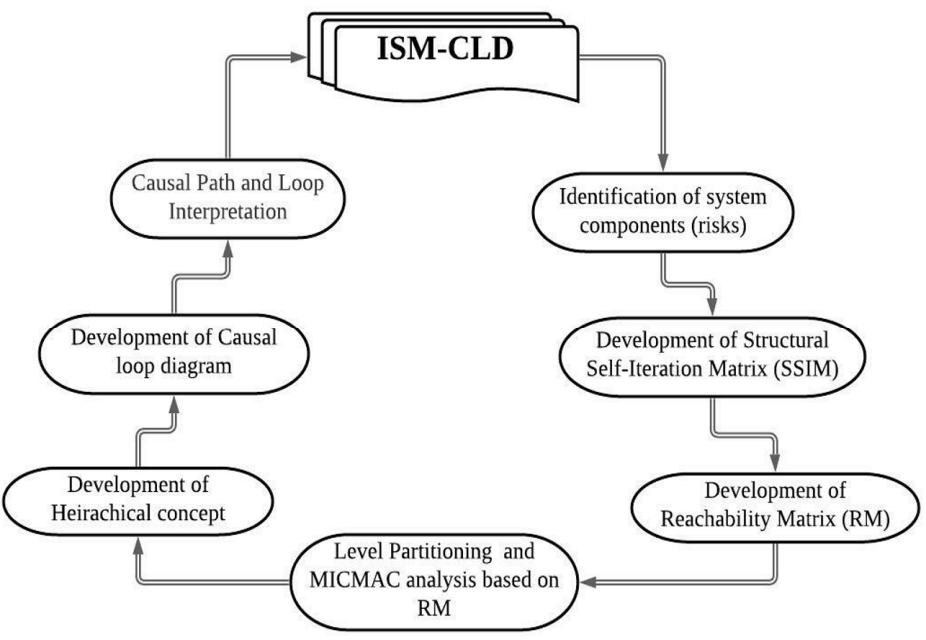

Figure 3. ISM-CLD Approach.

\subsection{Data Collection}

Risk evaluation using the ISM-CLD approach is an iterative and interpretive process and therefore requires the use of experts. Furthermore, the peculiarity of the Sino-African TPPPs requires engaging knowledgeable and experienced participants. Thus, primary data was elicited through expert semi-structured interviews. Prior to expert engagement, a comprehensive review of literature identified risks associated with transnational publicprivate partnerships in public infrastructure procurement. Furthermore, the review focused on case study papers on several projects in Africa to ensure generality. Based on the review findings, the expert interview was conducted for scoping of risk factors pertinent to SinoAfrica dealings as well as capturing risk factors eluded during literature review. The experts were also engaged as part of the ISM-CLD approach to establish relationships amongst risk factors similar to the study by [29].

\section{Analysis and Results}

\subsection{Expert Profile}

The integration of the ISM-CLD makes expert engagement integral to the problemsolving process. Moreover, the Sino-Africa dealings are unique and require in-depth knowledge and experience to realistically probe. There is no specified criterion on the number of experts to be engaged and the ISM approach does not require many respondents as much focus is placed on the experience and proficiency of respondents on the problem being analysed $[67,71]$ using the ISM, sampled three experts and developed a structural relationship between lean implementation barriers. Further, Ref. [68] used four experts in their ISM modelling approach for identifying the failure paths of PPP water projects. The ISM thus produces reliable findings even with few experts due to its logic and analytical rigour $[68,72]$. The heterogeneity of the population should be considered [66], hence this 
study involved experts from the private sector (Sino), the public sector (African contracting authorities), and academic researchers in the field of risk management and public-private partnerships. Through snowballing, forty-seven experts were contacted and thirteen accepted the invitation. The number was adequate to produce reliable findings based on their level of experience coupled with the ISM process adopted. The experts described the study area (Sino-Africa infrastructure dealings) as sensitive and their participation was dependent on a guarantee to ensure anonymity in their identities, given the depth of information and engaging process of the ISM-CLD approach. Table 2 shows the profile of experts engaged.

Table 2. Profile of Experts.

\begin{tabular}{|c|c|c|c|c|c|}
\hline Expert & Experience & Profession/Job Position & No. of Projects & Project Types & Countries of Work \\
\hline \multicolumn{6}{|c|}{ Public Sector (procurement authorities, PPP units or agencies, ministries, local government) } \\
\hline A & 11 years & $\begin{array}{l}\text { Administrator/Projects } \\
\text { manager }\end{array}$ & 15 to 20 & Transport, housing & Ghana \\
\hline B & 11 years & Quantity Surveyor & 12 to 15 & Transport & Tanzania \& Nigeria \\
\hline $\mathrm{C}$ & 15 years & Projects manager & Over 15 & Transport, energy & Ghana \& South Africa \\
\hline $\mathrm{D}$ & 19 years & $\begin{array}{c}\text { Administrative } \\
\text { head/contracts manager }\end{array}$ & 23 to 30 & Transport & Nigeria \\
\hline E & 22 years & Civil engineer & Over 20 & Transport \& oil and gas & Nigeria \\
\hline $\mathrm{F}$ & 16 years & Consultant (QS) & Over 15 & Transport, energy & Ghana, Angola \\
\hline \multicolumn{6}{|c|}{ Private Sector (Sino state-owned construction and engineering corporations) } \\
\hline G & 17 years & Engineer & 30 to 40 & Transport \& Energy & $\begin{array}{l}\text { Nigeria, Kenya, Angola, Togo } \\
\text { \& Ethiopia }\end{array}$ \\
\hline $\mathrm{H}$ & 15 years & Construction Manager & 30 to 40 & Transport, Energy \& water & Ghana \& Nigeria \\
\hline I & 11 years & Project Manager & 40 to 45 & Transport & $\begin{array}{l}\text { South Africa, Nigeria, Ghana } \\
\text { \& Kenya }\end{array}$ \\
\hline $\mathrm{b}$ & 13 years & Engineer & 20 to 30 & Transport, water \& housing & Ivory Coast, Congo \& Ghana \\
\hline \multicolumn{6}{|c|}{ Academic researcher (universities) } \\
\hline K & 10 years & Reader & $\mathrm{N} / \mathrm{A}$ & $\begin{array}{c}\text { Transport, housing and } \\
\text { energy }\end{array}$ & United Kingdom \\
\hline $\mathrm{L}$ & 16 years & Associate Professor & $\mathrm{N} / \mathrm{A}$ & Transport, housing \& water & Ghana \\
\hline M & 17 years & Associate Professor & $\mathrm{N} / \mathrm{A}$ & Transport & Nigeria \\
\hline
\end{tabular}

Common to all experts was apt knowledge in public infrastructure implementation. The transport sector includes sea and land ports, roads bridges, and railways. Similarly, aside from residential, the housing includes commercial and business infrastructure like factories. The interviews were conducted in English and were based on the ISM principle which was developed into an interview guide to ensure standardised information elicitation for the study. This also helped to check bias and ensure uniformity in the entire process.

\subsection{Components Identification}

Components for the systemic modelling were identified based on a combined process of extensive literature review and expert roundtable. Literature on transnational public and private collaboration for public infrastructure delivery was reviewed coupled with studies of Sino-Africa dealings. In the TPPP setting, the allocation of risk is paramount therefore review was focused on identifying the commonly allocated risks, see Table 1. Knowledge depth and focus are critical in ISM-CLD; therefore, the study adopted semi-structured expert interviews. The identification of the pertinent risks is obtained through interaction with experts from their practical and/or research experiences in Sino-Africa TPPPs. Experts were engaged in two phases, first to identify risk factors and consequently establish their relationships. The expert interview drew up twenty-two risk factors associated with the partnership between Chinese corporations and African governments for the delivery of 
public infrastructure. These factors are described in Table 3. Results from the literature review were used as the basis for experts to outline the pertinent risks and offer experiencebased descriptions of the risk factors. An ISM tool was used to aid in establishing the relationships using pairwise logic. Thematic content was used in the identification and delineation of pertinent risks, it involves an iterative process of identifying evaluating and reporting themes from data analysis [73]. The themes, i.e., risk factors and descriptions presented in Table 3 embody the patterned responses and meanings drawn from the data.

Table 3. Risk Factors in Sino-Africa TPPPs.

\begin{tabular}{ccc}
\hline ID & Risks & Delineation \\
\hline R1 & Bribery and corruption & $\begin{array}{c}\text { Fraudulent and opportunistic actions of either party especially during the } \\
\text { procurement process which affect other project attributes such as cost and quality. }\end{array}$ \\
\hline R2 & $\begin{array}{c}\text { Government or Political } \\
\text { Instability }\end{array}$ & $\begin{array}{c}\text { Changes and interference of government that negatively affects the smooth running } \\
\text { and sometimes abandonment of the project. }\end{array}$ \\
\hline R3 & $\begin{array}{c}\text { Regulatory framework and } \\
\text { policy monitoring risk }\end{array}$ & $\begin{array}{c}\text { Weak or lack of regulations and well-structured government institutions to effectively } \\
\text { oversee Sino infrastructure investments in the region despite its uniqueness. }\end{array}$ \\
\hline R4 & Force Majeure Risk & $\begin{array}{c}\text { Events of nature beyond the control of either party affecting the obligatory duties of } \\
\text { either or both project actors. }\end{array}$ \\
\hline
\end{tabular}

R5 Public opposition to the project

Resistance and lack of support from the local community due to the absence of inclusiveness in project planning and execution as well as public displeasure with project due to cultural and social impact.

\begin{tabular}{|c|c|c|}
\hline R6 & $\begin{array}{l}\text { Unfavourable host country } \\
\text { economy }\end{array}$ & $\begin{array}{l}\text { The instability and unhealthy financial systems and low purchasing power that limit } \\
\text { the investment friendliness thereby affecting the project cash flow. }\end{array}$ \\
\hline R7 & $\begin{array}{l}\text { Cultural and communication } \\
\text { risk }\end{array}$ & $\begin{array}{l}\text { The differences in culture and communication dimensions which may result in limited } \\
\text { interaction or misinterpretation of project information and tasks. }\end{array}$ \\
\hline R8 & $\begin{array}{l}\text { High cost of operation and } \\
\text { maintenance }\end{array}$ & The increase in the cost of the day-to-day administration of the public facility. \\
\hline R9 & Market demand changes & $\begin{array}{l}\text { These pertain to the changes in the market niche for public service provided which } \\
\text { may be due to faulty projections, needs analysis, or service quality. }\end{array}$ \\
\hline R10 & $\begin{array}{l}\text { Inadequate supporting } \\
\text { infrastructure }\end{array}$ & $\begin{array}{l}\text { The projects sometimes require some systems or existing structures to function well, } \\
\text { e.g., Linking roads in transport projects. }\end{array}$ \\
\hline R11 & Legal and regulatory changes & Changes in law or legislation in relation to taxes and industrial practices. \\
\hline R12 & $\begin{array}{l}\text { Project performance and Quality } \\
\text { risk }\end{array}$ & $\begin{array}{l}\text { The inability of the infrastructure to meet expectation and quality performance } \\
\text { standards. }\end{array}$ \\
\hline R13 & Environmental risks & $\begin{array}{l}\text { The effects of the project on the environment such as air, water, waste, land, and noise } \\
\text { pollution. }\end{array}$ \\
\hline R14 & $\begin{array}{l}\text { Poor contract design and } \\
\text { management }\end{array}$ & $\begin{array}{l}\text { Contract ambiguities, faulty and inconsistent contract agreements, and partnership } \\
\text { dealings which may harm communication in project execution. }\end{array}$ \\
\hline R15 & Project Cost overrun & $\begin{array}{l}\text { The inability to execute and operate projects within budget attributable to faulty } \\
\text { financial forecasts and economic environment. }\end{array}$ \\
\hline R16 & Poor project feasibility studies & $\begin{array}{l}\text { Inability to efficiently determine the socio-economic viability of the project through } \\
\text { errors in needs assessments. }\end{array}$ \\
\hline R17 & $\begin{array}{l}\text { Poor/lengthy public } \\
\text { decision-making process }\end{array}$ & $\begin{array}{l}\text { Inadequate or lengthy negotiation in the contract closure due to conflict of interests } \\
\text { and unbalanced bargaining strength and ability of either party. }\end{array}$ \\
\hline R18 & High project finance & $\begin{array}{l}\text { The risk of investing owing to the high cost of borrowing amid uncertainties in the } \\
\text { investment climate of most developing economies. }\end{array}$ \\
\hline R19 & Land acquisition & $\begin{array}{l}\text { Delays in gaining access to the site or land unavailability issues that may affect project } \\
\text { commencement and construction activities. }\end{array}$ \\
\hline R20 & Foreign exchange risks & $\begin{array}{l}\text { The fluctuation and poor performance of local currency against foreign currencies } \\
\text { which may pose limitations on imports. }\end{array}$ \\
\hline
\end{tabular}


Table 3. Cont.

\begin{tabular}{ccc}
\hline ID & Risks & Delineation \\
\hline R21 & $\begin{array}{c}\text { Poor sharing of risk and } \\
\text { responsibilities }\end{array}$ & $\begin{array}{c}\text { Failure to effectively allocate risks, responsibilities, and authorities prior to } \\
\text { commencement leading to the dire consequence of mismanagement. }\end{array}$ \\
\hline R22 & Delayed project Schedule & The inability to meet the agreed contract period for project execution. \\
\hline
\end{tabular}

\subsection{Systemic Risk Evaluation (ISM-CLD)}

\subsubsection{Structural Self-Interaction Matrix (SSIM)}

This establishes the relationships among risk factors using a pairwise comparator where the columns and rows are denoted with i and j, respectively. V, A, X, and O are used to denote the description of relationships between the risk factors. The risk factors are built into a matrix and captured on an $x$ and $y$-axis pane such that a cell Rij in the matrix shows the interaction between $\mathrm{Ri}$ and $\mathrm{Rj}$ on the $x$ and $y$-axis, respectively. The VAXO connotes the following:

$\mathrm{V}=\mathrm{Ri}$ influences $\mathrm{Rj}$ whereas $\mathrm{Rj}$ does not influence Ri;

$A=R j$ influences $R i$ whereas $R i$ does not influence $R j ;$

$\mathrm{X}=\mathrm{Ri}$ influences $\mathrm{Rj}$ and $\mathrm{Rj}$ influences $\mathrm{Ri}$;

$\mathrm{O}=\mathrm{Ri}$ and $\mathrm{Rj}$ are unrelated.

The interpretive logic and direct relationship amongst the risk factors is presented in the Table 4.

Table 4. Structural Self-Interaction Matrix (SSIM).

\begin{tabular}{|c|c|c|c|c|c|c|c|c|c|c|c|c|c|c|c|c|c|c|c|c|c|c|}
\hline & R22 & $\mathbf{R} 21$ & R20 & R19 & R18 & R17 & R16 & R15 & R14 & R13 & R12 & R11 & R10 & R9 & R8 & R7 & R6 & R5 & R4 & R3 & R2 & R1 \\
\hline R1 & $\mathrm{V}$ & $\mathrm{V}$ & $\mathrm{O}$ & A & $\mathrm{V}$ & $\mathrm{O}$ & $\mathrm{O}$ & $\mathrm{V}$ & $x$ & $\mathrm{O}$ & $\mathrm{V}$ & $\mathrm{O}$ & $\mathrm{O}$ & $\mathrm{O}$ & $\mathrm{V}$ & $\mathrm{O}$ & $x$ & A & $\mathrm{O}$ & A & A & $x$ \\
\hline R2 & $\mathrm{V}$ & $\mathrm{O}$ & $\mathrm{O}$ & $\mathrm{V}$ & $\mathrm{O}$ & $\mathrm{V}$ & $\mathrm{O}$ & $\mathrm{V}$ & $\mathrm{O}$ & $\mathrm{O}$ & $\mathrm{V}$ & $x$ & $\mathrm{~V}$ & $\mathrm{O}$ & $\mathrm{O}$ & $\mathrm{V}$ & $\mathrm{V}$ & $\mathrm{V}$ & $\mathrm{O}$ & $x$ & $x$ & \\
\hline R3 & $\mathrm{V}$ & $\mathrm{V}$ & $\mathrm{O}$ & $\mathrm{O}$ & $\mathrm{V}$ & $\mathrm{O}$ & $\mathrm{O}$ & $\mathrm{V}$ & $\mathrm{V}$ & $\mathrm{O}$ & $\mathrm{V}$ & $x$ & $\mathrm{O}$ & $\mathrm{O}$ & $\mathrm{V}$ & $\mathrm{V}$ & $\mathrm{O}$ & $\mathrm{O}$ & A & $x$ & & \\
\hline R4 & $\mathrm{V}$ & $\mathrm{O}$ & $\mathrm{V}$ & $\mathrm{V}$ & $\mathrm{V}$ & $\mathrm{O}$ & $\mathrm{V}$ & $\mathrm{V}$ & $\mathrm{O}$ & $\mathrm{O}$ & $\mathrm{V}$ & $\mathrm{O}$ & $\mathrm{O}$ & $\mathrm{O}$ & $\mathrm{V}$ & $\mathrm{O}$ & $\mathrm{O}$ & $\mathrm{O}$ & $x$ & & & \\
\hline R5 & $x$ & $\mathrm{~A}$ & $\mathrm{O}$ & $\mathrm{V}$ & $\mathrm{A}$ & $\mathrm{V}$ & $\mathrm{O}$ & $\mathrm{V}$ & $\mathrm{O}$ & $\mathrm{A}$ & $x$ & $\mathrm{~A}$ & $\mathrm{~A}$ & $\mathrm{~V}$ & $\mathrm{O}$ & $\mathrm{O}$ & $\mathrm{O}$ & $x$ & & & & \\
\hline R6 & $\mathrm{O}$ & $\mathrm{O}$ & $x$ & $\mathrm{O}$ & $\mathrm{V}$ & $\mathrm{O}$ & $\mathrm{O}$ & $\mathrm{V}$ & $\mathrm{O}$ & $\mathrm{O}$ & $x$ & A & $\mathrm{V}$ & $\mathrm{V}$ & $\mathrm{V}$ & $\mathrm{O}$ & $x$ & & & & & \\
\hline R7 & $\mathrm{V}$ & $\mathrm{V}$ & $\mathrm{O}$ & $\mathrm{O}$ & $\mathrm{O}$ & $\mathrm{V}$ & $\mathrm{O}$ & $\mathrm{O}$ & $x$ & $\mathrm{O}$ & $\mathrm{V}$ & $\mathrm{O}$ & $\mathrm{O}$ & $\mathrm{O}$ & $\mathrm{O}$ & $x$ & & & & & & \\
\hline R8 & A & $\mathrm{O}$ & A & $\mathrm{O}$ & $x$ & $\mathrm{O}$ & A & $x$ & $\mathrm{O}$ & $\mathrm{O}$ & $x$ & A & A & $x$ & $x$ & & & & & & & \\
\hline R9 & $\mathrm{O}$ & $\mathrm{O}$ & $\mathrm{A}$ & $\mathrm{O}$ & $\mathrm{V}$ & $\mathrm{O}$ & $\mathrm{A}$ & $\mathrm{V}$ & $\mathrm{O}$ & $\mathrm{A}$ & $x$ & A & $\mathrm{A}$ & $x$ & & & & & & & & \\
\hline R10 & $\mathrm{V}$ & $\mathrm{O}$ & $\mathrm{O}$ & $\mathrm{V}$ & $\mathrm{V}$ & $\mathrm{O}$ & $\mathrm{O}$ & $\mathrm{V}$ & $\mathrm{O}$ & $\mathrm{O}$ & $\mathrm{V}$ & $\mathrm{O}$ & $x$ & & & & & & & & & \\
\hline R11 & $\mathrm{V}$ & $\mathrm{O}$ & $\mathrm{O}$ & $\mathrm{O}$ & $\mathrm{V}$ & $\mathrm{V}$ & $\mathrm{O}$ & $\mathrm{V}$ & $\mathrm{V}$ & $\mathrm{O}$ & $\mathrm{V}$ & $x$ & & & & & & & & & & \\
\hline R12 & $\mathrm{A}$ & $\mathrm{A}$ & $\mathrm{A}$ & $\mathrm{O}$ & A & $\mathrm{O}$ & $\mathrm{A}$ & A & A & $\mathrm{A}$ & $x$ & & & & & & & & & & & \\
\hline R13 & $\mathrm{O}$ & $\mathrm{O}$ & $\mathrm{O}$ & $\mathrm{V}$ & $\mathrm{O}$ & $\mathrm{O}$ & A & $\mathrm{O}$ & $\mathrm{O}$ & $x$ & & & & & & & & & & & & \\
\hline R14 & $\mathrm{V}$ & $\mathrm{V}$ & $\mathrm{O}$ & $\mathrm{O}$ & $\mathrm{V}$ & A & $\mathrm{A}$ & $\mathrm{V}$ & $x$ & & & & & & & & & & & & & \\
\hline R15 & $x$ & $\mathrm{~A}$ & $\mathrm{~A}$ & $\mathrm{O}$ & $x$ & A & A & $x$ & & & & & & & & & & & & & & \\
\hline R16 & $\mathrm{V}$ & $\mathrm{O}$ & $\mathrm{O}$ & $\mathrm{A}$ & $\mathrm{O}$ & $\mathrm{O}$ & $x$ & & & & & & & & & & & & & & & \\
\hline R17 & $\mathrm{V}$ & $\mathrm{V}$ & $\mathrm{O}$ & $\mathrm{O}$ & $\mathrm{O}$ & $x$ & & & & & & & & & & & & & & & & \\
\hline R18 & $\mathrm{O}$ & $\mathrm{O}$ & $\mathrm{A}$ & A & $x$ & & & & & & & & & & & & & & & & & \\
\hline R19 & $\mathrm{V}$ & $\mathrm{O}$ & $\mathrm{O}$ & $x$ & & & & & & & & & & & & & & & & & & \\
\hline R20 & $\mathrm{O}$ & $\mathrm{O}$ & $x$ & & & & & & & & & & & & & & & & & & & \\
\hline R21 & $\mathrm{V}$ & $X$ & & & & & & & & & & & & & & & & & & & & \\
\hline R22 & $x$ & & & & & & & & & & & & & & & & & & & & & \\
\hline
\end{tabular}

\subsubsection{Reachability Matrix (RM)}

The initial reachability matrix is developed from the SSIM which involves conversion from the VOAX matrix into a binary matrix. This is achieved from conditional statements on the interpretation of the VOAX into either 1 or 0 on the $x$ and $y$ axis. The conditions are that given the cell ij entry in the SSIM, the connotation is:

$\mathrm{V}$, the ij cell becomes 1 and the ji cell becomes 0 ; 
A, the ij cell becomes 0 and the ji cell becomes 1 ;

$\mathrm{X}$, the ij cell becomes 1 and the ji cell becomes 1 ;

$\mathrm{O}$, the ij cell becomes 0 and the ji cell becomes 0 .

For instance, cell R3R4 is A the binary conversion is 0 for R3R4 and 1 for R4R3. The results of the $22 \times 22$ binary matrix of risk relationships are presented in Table 5 .

Table 5. Initial Reachability Matrix.

\begin{tabular}{|c|c|c|c|c|c|c|c|c|c|c|c|c|c|c|c|c|c|c|c|c|c|c|}
\hline & R1 & R2 & R3 & R4 & R5 & R6 & R7 & R8 & R9 & R10 & R11 & R12 & R13 & R14 & R15 & R16 & R17 & R18 & R19 & R20 & R21 & R22 \\
\hline R1 & 1 & 0 & 0 & 0 & 0 & 1 & 0 & 1 & 0 & 0 & 0 & 1 & 0 & 1 & 1 & 0 & 0 & 1 & 0 & 0 & 1 & 1 \\
\hline R2 & 1 & 1 & 1 & 0 & 1 & 1 & 1 & 0 & 0 & 1 & 1 & 1 & 0 & 0 & 1 & 0 & 1 & 0 & 1 & 0 & 0 & 1 \\
\hline R3 & 1 & 1 & 1 & 0 & 0 & 0 & 1 & 1 & 0 & 0 & 1 & 1 & 0 & 1 & 1 & 0 & 0 & 1 & 0 & 0 & 1 & 1 \\
\hline R4 & 0 & 0 & 1 & 1 & 0 & 0 & 0 & 1 & 0 & 0 & 0 & 1 & 0 & 0 & 1 & 1 & 0 & 1 & 1 & 1 & 0 & 1 \\
\hline R5 & 1 & 0 & 0 & 0 & 1 & 0 & 0 & 0 & 1 & 0 & 0 & 1 & 0 & 0 & 1 & 0 & 1 & 0 & 1 & 0 & 0 & 1 \\
\hline R6 & 1 & 0 & 0 & 0 & 0 & 1 & 0 & 1 & 1 & 1 & 0 & 1 & 0 & 0 & 1 & 0 & 0 & 1 & 0 & 1 & 0 & 0 \\
\hline R7 & 0 & 0 & 0 & 0 & 0 & 0 & 1 & 0 & 0 & 0 & 0 & 1 & 0 & 1 & 0 & 0 & 1 & 0 & 0 & 0 & 1 & 1 \\
\hline R8 & 1 & 0 & 0 & 0 & 0 & 0 & 0 & 1 & 1 & 0 & 0 & 1 & 0 & 0 & 1 & 0 & 0 & 1 & 0 & 0 & 0 & 0 \\
\hline R9 & 0 & 0 & 0 & 0 & 0 & 0 & 0 & 1 & 1 & 0 & 0 & 1 & 0 & 0 & 1 & 0 & 0 & 1 & 0 & 0 & 0 & 0 \\
\hline R10 & 0 & 0 & 0 & 0 & 1 & 0 & 0 & 1 & 1 & 1 & 0 & 1 & 0 & 0 & 1 & 0 & 0 & 1 & 1 & 0 & 0 & 1 \\
\hline R11 & 0 & 1 & 1 & 0 & 1 & 1 & 0 & 1 & 1 & 0 & 1 & 1 & 0 & 1 & 1 & 0 & 1 & 1 & 0 & 0 & 0 & 1 \\
\hline R12 & 0 & 0 & 0 & 0 & 1 & 1 & 0 & 1 & 1 & 0 & 0 & 1 & 0 & 0 & 0 & 0 & 0 & 0 & 0 & 0 & 0 & 0 \\
\hline R13 & 0 & 0 & 0 & 0 & 1 & 0 & 0 & 0 & 1 & 0 & 0 & 1 & 1 & 0 & 0 & 0 & 0 & 0 & 1 & 0 & 0 & 0 \\
\hline R14 & 1 & 0 & 0 & 0 & 0 & 0 & 1 & 0 & 0 & 0 & 0 & 1 & 0 & 1 & 1 & 0 & 0 & 1 & 0 & 0 & 1 & 1 \\
\hline R15 & 0 & 0 & 0 & 0 & 0 & 0 & 0 & 1 & 0 & 0 & 0 & 1 & 0 & 0 & 1 & 0 & 0 & 1 & 0 & 0 & 0 & 1 \\
\hline R16 & 0 & 0 & 0 & 0 & 0 & 0 & 0 & 1 & 1 & 0 & 0 & 1 & 1 & 1 & 1 & 1 & 0 & 0 & 0 & 0 & 0 & 1 \\
\hline R17 & 0 & 0 & 0 & 0 & 0 & 0 & 0 & 0 & 0 & 0 & 0 & 0 & 0 & 1 & 1 & 0 & 1 & 0 & 0 & 0 & 1 & 1 \\
\hline R18 & 0 & 0 & 0 & 0 & 1 & 0 & 0 & 1 & 0 & 0 & 0 & 1 & 0 & 0 & 1 & 0 & 0 & 1 & 0 & 0 & 0 & 0 \\
\hline R19 & 0 & 0 & 0 & 0 & 0 & 0 & 0 & 0 & 0 & 0 & 0 & 0 & 0 & 0 & 0 & 1 & 0 & 1 & 1 & 0 & 0 & 1 \\
\hline R20 & 0 & 0 & 0 & 0 & 0 & 1 & 0 & 1 & 1 & 0 & 0 & 1 & 0 & 0 & 1 & 0 & 0 & 1 & 0 & 1 & 0 & 0 \\
\hline R21 & 0 & 0 & 0 & 0 & 1 & 0 & 0 & 0 & 0 & 0 & 0 & 1 & 0 & 0 & 1 & 0 & 0 & 0 & 0 & 0 & 1 & 1 \\
\hline R22 & 0 & 0 & 0 & 0 & 1 & 0 & 0 & 1 & 0 & 0 & 0 & 1 & 0 & 0 & 1 & 1 & 0 & 0 & 0 & 0 & 0 & 1 \\
\hline
\end{tabular}

\subsubsection{Final Reachability Matrix}

This paper is focused on evaluating risks using systems thinking; however, the initial matrix establishes the direct relationships among the risk factors. In order to obtain both direct and indirect relationships, the transitivity check is used. Transitivity checks are established based on the premise that if R1 has a relationship with R2 and R2 has a relationship with R3 then R1 has a relationship with R3. The check for transitive links can be tricky and a manual approach for a huge matrix is cumbersome and require an automated process for precision. A function was developed in Python (see Appendix A for code) and was used in this process, which generated the final reachability matrix similar to [74].

The MICMAC analysis uses the driving and dependency powers of the risk factors as shown in Table 6. 
Table 6. Final Reachability Matrix.

\begin{tabular}{|c|c|c|c|c|c|c|c|c|c|c|c|c|c|c|c|c|c|c|c|c|c|c|c|}
\hline & R1 & R2 & R3 & R4 & R5 & R6 & R7 & R8 & R9 & R10 & R11 & R12 & R13 & R14 & R15 & R16 & R17 & R18 & R19 & R20 & R21 & $\mathbf{R} 22$ & Driving \\
\hline R1 & 1 & 0 & 0 & 0 & 1 & 1 & 1 & 1 & 1 & 1 & 0 & 1 & 1 & 1 & 1 & 1 & 1 & 1 & 1 & 1 & 1 & 1 & 18 \\
\hline R2 & 1 & 1 & 1 & 0 & 1 & 1 & 1 & 1 & 1 & 1 & 1 & 1 & 1 & 1 & 1 & 1 & 1 & 1 & 1 & 1 & 1 & 1 & 21 \\
\hline R3 & 1 & 1 & 1 & 0 & 1 & 1 & 1 & 1 & 1 & 1 & 1 & 1 & 1 & 1 & 1 & 1 & 1 & 1 & 1 & 1 & 1 & 1 & 21 \\
\hline R4 & 1 & 1 & 1 & 1 & 1 & 1 & 1 & 1 & 1 & 1 & 1 & 1 & 1 & 1 & 1 & 1 & 1 & 1 & 1 & 1 & 1 & 1 & 22 \\
\hline R5 & 1 & 0 & 0 & 0 & 1 & 1 & 1 & 1 & 1 & 1 & 0 & 1 & 1 & 1 & 1 & 1 & 1 & 1 & 1 & 1 & 1 & 1 & 18 \\
\hline R6 & 1 & 0 & 0 & 0 & 1 & 1 & 1 & 1 & 1 & 1 & 0 & 1 & 1 & 1 & 1 & 1 & 1 & 1 & 1 & 1 & 1 & 1 & 18 \\
\hline R7 & 1 & 0 & 0 & 0 & 1 & 1 & 1 & 1 & 1 & 1 & 0 & 1 & 1 & 1 & 1 & 1 & 1 & 1 & 1 & 1 & 1 & 1 & 18 \\
\hline R9 & 1 & 0 & 0 & 0 & 1 & 1 & 1 & 1 & 1 & 1 & 0 & 1 & 1 & 1 & 1 & 1 & 1 & 1 & 1 & 1 & 1 & 1 & 18 \\
\hline R10 & 1 & 0 & 0 & 0 & 1 & 1 & 1 & 1 & 1 & 1 & 0 & 1 & 1 & 1 & 1 & 1 & 1 & 1 & 1 & 1 & 1 & 1 & 18 \\
\hline R11 & 1 & 1 & 1 & 0 & 1 & 1 & 1 & 1 & 1 & 1 & 1 & 1 & 1 & 1 & 1 & 1 & 1 & 1 & 1 & 1 & 1 & 1 & 21 \\
\hline R12 & 1 & 0 & 0 & 0 & 1 & 1 & 1 & 1 & 1 & 1 & 0 & 1 & 1 & 1 & 1 & 1 & 1 & 1 & 1 & 1 & 1 & 1 & 18 \\
\hline R13 & 1 & 0 & 0 & 0 & 1 & 1 & 1 & 1 & 1 & 1 & 0 & 1 & 1 & 1 & 1 & 1 & 1 & 1 & 1 & 1 & 1 & 1 & 18 \\
\hline R14 & 1 & 0 & 0 & 0 & 1 & 1 & 1 & 1 & 1 & 1 & 0 & 1 & 1 & 1 & 1 & 1 & 1 & 1 & 1 & 1 & 1 & 1 & 18 \\
\hline R15 & 1 & 0 & 0 & 0 & 1 & 1 & 1 & 1 & 1 & 1 & 0 & 1 & 1 & 1 & 1 & 1 & 1 & 1 & 1 & 1 & 1 & 1 & 18 \\
\hline R16 & 1 & 0 & 0 & 0 & 1 & 1 & 1 & 1 & 1 & 1 & 0 & 1 & 1 & 1 & 1 & 1 & 1 & 1 & 1 & 1 & 1 & 1 & 18 \\
\hline R18 & 1 & 0 & 0 & 0 & 1 & 1 & 1 & 1 & 1 & 1 & 0 & 1 & 1 & 1 & 1 & 1 & 1 & 1 & 1 & 1 & 1 & 1 & 18 \\
\hline R19 & 1 & 0 & 0 & 0 & 1 & 1 & 1 & 1 & 1 & 1 & 0 & 1 & 1 & 1 & 1 & 1 & 1 & 1 & 1 & 1 & 1 & 1 & 18 \\
\hline R20 & 1 & 0 & 0 & 0 & 1 & 1 & 1 & 1 & 1 & 1 & 0 & 1 & 1 & 1 & 1 & 1 & 1 & 1 & 1 & 1 & 1 & 1 & 18 \\
\hline R21 & 1 & 0 & 0 & 0 & 1 & 1 & 1 & 1 & 1 & 1 & 0 & 1 & 1 & 1 & 1 & 1 & 1 & 1 & 1 & 1 & 1 & 1 & 18 \\
\hline R22 & 1 & 0 & 0 & 0 & 1 & 1 & 1 & 1 & 1 & 1 & 0 & 1 & 1 & 1 & 1 & 1 & 1 & 1 & 1 & 1 & 1 & 1 & 18 \\
\hline Dependence & 22 & 4 & 4 & 1 & 22 & 22 & 22 & 22 & 22 & 22 & 4 & 22 & 22 & 22 & 22 & 22 & 22 & 22 & 22 & 22 & 22 & 22 & \\
\hline
\end{tabular}




\subsubsection{Level Partitioning}

The hierarchal structure and polarity of the risk relationships are ascertained at this level. This analysis involves computing the reachability set (Rs), antecedent set (As), and intersection set (Is). The risk factors with the corresponding value of 1 (including itself) on the row from the final RM matrix make up the reachability set. Similarly, the respective risk factors with a value of 1 on the column make the antecedent set. The common risk factors in the reachability and the antecedent sets constitute the intersection set. The hierarchical partitioning rule states that the risk factors are classified to a common level if Rs makes a proper subset of Is. Thus, the partitioning of risks into levels follows an iterative process of (i) identifying risks with the same elements in the reachability and the intersection column, and (ii) eliminating the risk factors from the table and repeating the initial step. This process is done until all risk factors are labelled and partitioned. For instance, R1 has the same elements in Rs and Is and therefore partitioned in level one, similarly for R5 and so on. The iterative level partitioning process in presented in Table 7.

Table 7. Level partitioning.

\begin{tabular}{|c|c|c|c|c|}
\hline Risk & Reachability Set & Antecedent Set & Intersection Set & Level \\
\hline \multicolumn{5}{|c|}{ Level 1} \\
\hline R1 & $1,5,6,7,8,9,10,12,13,14,15,16,17,18,19,20,21,22$ & $1,2,3,4,5,6,7,8,9,10,11,12,13,14,15,16,17,18,19,20,21,22$ & $1,5,6,7,8,9,10,12,13,14,15,16,17,18,19,20,21,22$ & I \\
\hline $\mathrm{R} 2$ & $\begin{array}{c}1,2,3,5,6,7,8,9,10,11,12,13,14,15,16,17,18,19,20 \\
21,22\end{array}$ & $2,3,4,11$ & $2,3,11$ & \\
\hline R3 & $\begin{array}{c}1,2,3,5,6,7,8,9,10,11,12,13,14,15,16,17,18,19,20 \\
21,22\end{array}$ & $2,3,4,11$ & $2,3,11$ & \\
\hline R4 & $\begin{array}{c}1,2,3,4,5,6,7,8,9,10,11,12,13,14,15,16,17,18,19,20 \\
21,22\end{array}$ & 4 & 4 & \\
\hline R5 & $1,5,6,7,8,9,10,12,13,14,15,16,17,18,18,20,21,22$ & $1,2,3,4,5,6,7,8,9,10,11,12,13,14,15,16,17,18,18,20,21,22$ & $1,5,6,7,8,9,10,12,13,14,15,16,17,18,18,20,21,22$ & I \\
\hline R6 & $1,5,6,7,8,9,10,12,13,14,15,16,17,18,18,20,21,22$ & $1,2,3,4,5,6,7,8,9,10,11,12,13,14,15,16,17,18,18,20,21,22$ & $1,5,6,7,8,9,10,12,13,14,15,16,17,18,18,20,21,22$ & I \\
\hline R7 & $1,5,6,7,8,9,10,12,13,14,15,16,17,18,18,20,21,22$ & $1,2,3,4,5,6,7,8,9,10,11,12,13,14,15,16,17,18,18,20,21,22$ & $1,5,6,7,8,9,10,12,13,14,15,16,17,18,18,20,21,22$ & I \\
\hline R8 & $1,5,6,7,8,9,10,12,13,14,15,16,17,18,18,20,21,22$ & $1,2,3,4,5,6,7,8,9,10,11,12,13,14,15,16,17,18,18,20,21,22$ & $1,5,6,7,8,9,10,12,13,14,15,16,17,18,18,20,21,22$ & I \\
\hline R9 & $1,5,6,7,8,9,10,12,13,14,15,16,17,18,18,20,21,22$ & $1,2,3,4,5,6,7,8,9,10,11,12,13,14,15,16,17,18,18,20,21,22$ & $1,5,6,7,8,9,10,12,13,14,15,16,17,18,18,20,21,22$ & I \\
\hline R10 & $1,5,6,7,8,9,10,12,13,14,15,16,17,18,18,20,21,22$ & $1,2,3,4,5,6,7,8,9,10,11,12,13,14,15,16,17,18,18,20,21,22$ & $1,5,6,7,8,9,10,12,13,14,15,16,17,18,18,20,21,22$ & I \\
\hline R11 & $\begin{array}{c}1,2,3,5,6,7,8,9,10,11,12,13,14,15,16,17,18,18,20 \\
21,22\end{array}$ & $2,3,4,11$ & $2,3,4,11$ & \\
\hline R12 & $1,5,6,7,8,9,10,12,13,14,15,16,17,18,18,20,21,22$ & $1,2,3,4,5,6,7,8,9,10,11,12,13,14,15,16,17,18,18,20,21,22$ & $1,5,6,7,8,9,10,12,13,14,15,16,17,18,18,20,21,22$ & I \\
\hline R13 & $1,5,6,7,8,9,10,12,13,14,15,16,17,18,18,20,21,22$ & $1,2,3,4,5,6,7,8,9,10,11,12,13,14,15,16,17,18,18,20,21,22$ & $1,5,6,7,8,9,10,12,13,14,15,16,17,18,18,20,21,22$ & I \\
\hline R14 & $1,5,6,7,8,9,10,12,13,14,15,16,17,18,18,20,21,22$ & $1,2,3,4,5,6,7,8,9,10,11,12,13,14,15,16,17,18,18,20,21,22$ & $1,5,6,7,8,9,10,12,13,14,15,16,17,18,18,20,21,22$ & I \\
\hline R15 & $1,5,6,7,8,9,10,12,13,14,15,16,17,18,18,20,21,22$ & $1,2,3,4,5,6,7,8,9,10,11,12,13,14,15,16,17,18,18,20,21,22$ & $1,5,6,7,8,9,10,12,13,14,15,16,17,18,18,20,21,22$ & I \\
\hline R16 & $1,5,6,7,8,9,10,12,13,14,15,16,17,18,18,20,21,22$ & $1,2,3,4,5,6,7,8,9,10,11,12,13,14,15,16,17,18,18,20,21,22$ & $1,5,6,7,8,9,10,12,13,14,15,16,17,18,18,20,21,22$ & I \\
\hline R17 & $1,5,6,7,8,9,10,12,13,14,15,16,17,18,18,20,21,22$ & $1,2,3,4,5,6,7,8,9,10,11,12,13,14,15,16,17,18,18,20,21,22$ & $1,5,6,7,8,9,10,12,13,14,15,16,17,18,18,20,21,22$ & I \\
\hline R18 & $1,5,6,7,8,9,10,12,13,14,15,16,17,18,18,20,21,22$ & $1,2,3,4,5,6,7,8,9,10,11,12,13,14,15,16,17,18,18,20,21,22$ & $1,5,6,7,8,9,10,12,13,14,15,16,17,18,18,20,21,22$ & I \\
\hline R19 & $1,5,6,7,8,9,10,12,13,14,15,16,17,18,18,20,21,22$ & $1,2,3,4,5,6,7,8,9,10,11,12,13,14,15,16,17,18,18,20,21,22$ & $1,5,6,7,8,9,10,12,13,14,15,16,17,18,18,20,21,22$ & I \\
\hline $\mathrm{R} 20$ & $1,5,6,7,8,9,10,12,13,14,15,16,17,18,18,20,21,22$ & $1,2,3,4,5,6,7,8,9,10,11,12,13,14,15,16,17,18,18,20,21,22$ & $1,5,6,7,8,9,10,12,13,14,15,16,17,18,18,20,21,22$ & I \\
\hline R21 & $1,5,6,7,8,9,10,12,13,14,15,16,17,18,18,20,21,22$ & $1,2,3,4,5,6,7,8,9,10,11,12,13,14,15,16,17,18,18,20,21,22$ & $1,5,6,7,8,9,10,12,13,14,15,16,17,18,18,20,21,22$ & I \\
\hline R22 & $1,5,6,7,8,9,10,12,13,14,15,16,17,18,18,20,21,22$ & $1,2,3,4,5,6,7,8,9,10,11,12,13,14,15,16,17,18,18,20,21,22$ & $1,5,6,7,8,9,10,12,13,14,15,16,17,18,18,20,21,22$ & I \\
\hline \multicolumn{5}{|c|}{ Level 2} \\
\hline R2 & $2,3,11$ & $2,3,4,11$ & $2,3,11$ & II \\
\hline R3 & $2,3,11$ & $2,3,4,11$ & $2,3,11$ & II \\
\hline $\mathrm{R} 4$ & $2,3,4,11$ & 4 & 4 & \\
\hline R11 & $2,3,11$ & $2,3,4,11$ & $2,3,11$ & II \\
\hline \multicolumn{5}{|c|}{ Level 3} \\
\hline R4 & 4 & 4 & 4 & III \\
\hline
\end{tabular}

The results present a three-level hierarchical structure based on the relationships amongst the risks factors. Level one featured 18 risk factors, three were captured in level 
two, and the third and final level had one risk factor. The higher the level the higher the driving power which implies that those risk factors influence the lower levels. For instance, R4, i.e., force majeure risk clustered in the highest level influences the occurrence of the other risks. A practical example is the COVID-19 pandemic, which has affected construction activities in most countries, economies, and industries. Furthermore, the risk factors in level two include government and political instability, weak regulatory frameworks and policy monitoring, and legal and regulatory changes. It is evident to note that these risks translate to the host country's governance structure and dynamics, which is a topical issue in transnational partnerships in developing countries. Figure 4 presents the hierarchical structure of the risk factors.

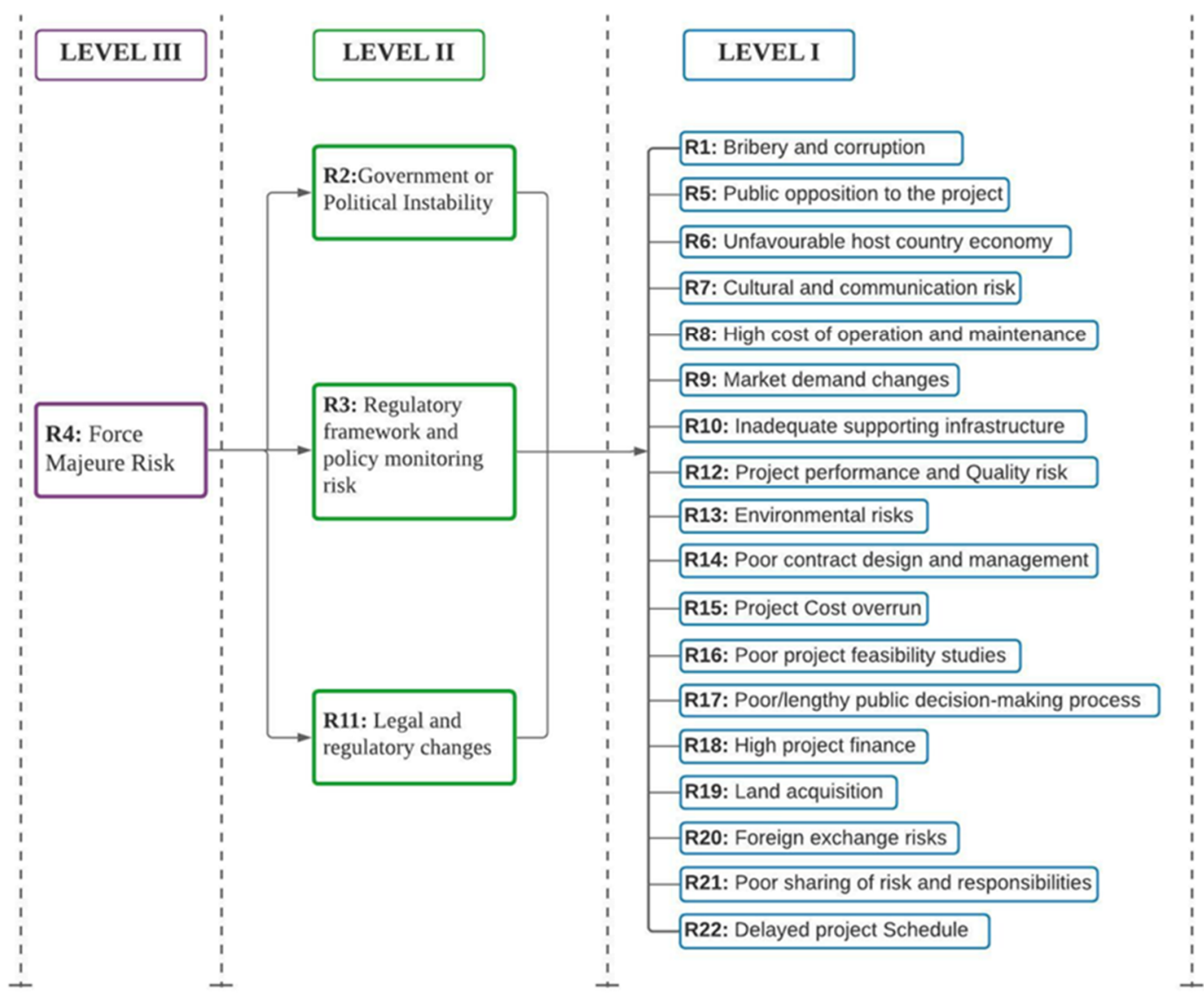

Figure 4. Hierarchical ISM Diagram.

\subsubsection{MICMAC Analysis}

Upon development of the hierarchical structure of the risk factors, the nature of the risk relationships is determined by the MICMAC analysis, which is also referred to as the cross-impact matrix multiplication. Ascertaining the attributes of the risk relationships is essential as it provides interpretive grounds for effective planning and control. Based on the magnitude of driving and dependence powers of the individual risk factors computed in the final reachability matrix, the MICMAC analysis reveals the individual attributes of the risk factors. The MICMAC adopts graphical plotting and sectioning of risk factors into four quadrants, namely, autonomous, dependent, independent, or linkage risk factors. The autonomous quadrant describes the risk factors that have low driving power and low dependency power and are considered to be somewhat disconnected from the system. The dependent quadrant envelopes those risk factors that have high dependency power and low driving power, and therefore the occurrence of those risks is highly dependent on other factors. In addition, the independent factors have high driving power and low dependency power, meaning that those risk factors are highly influential in the system. Finally, the 
linkage quadrant holds risk factors that have both high dependency and driving powers, meaning that they are unstable and can be affected as much as they affect other risk factors in the system. The sum of rows on the final RM matrix is the driving power which makes the $y$-axis and the sum of individual columns makes up the dependency power on the $x$-axis. The results are shown in Figure 5.

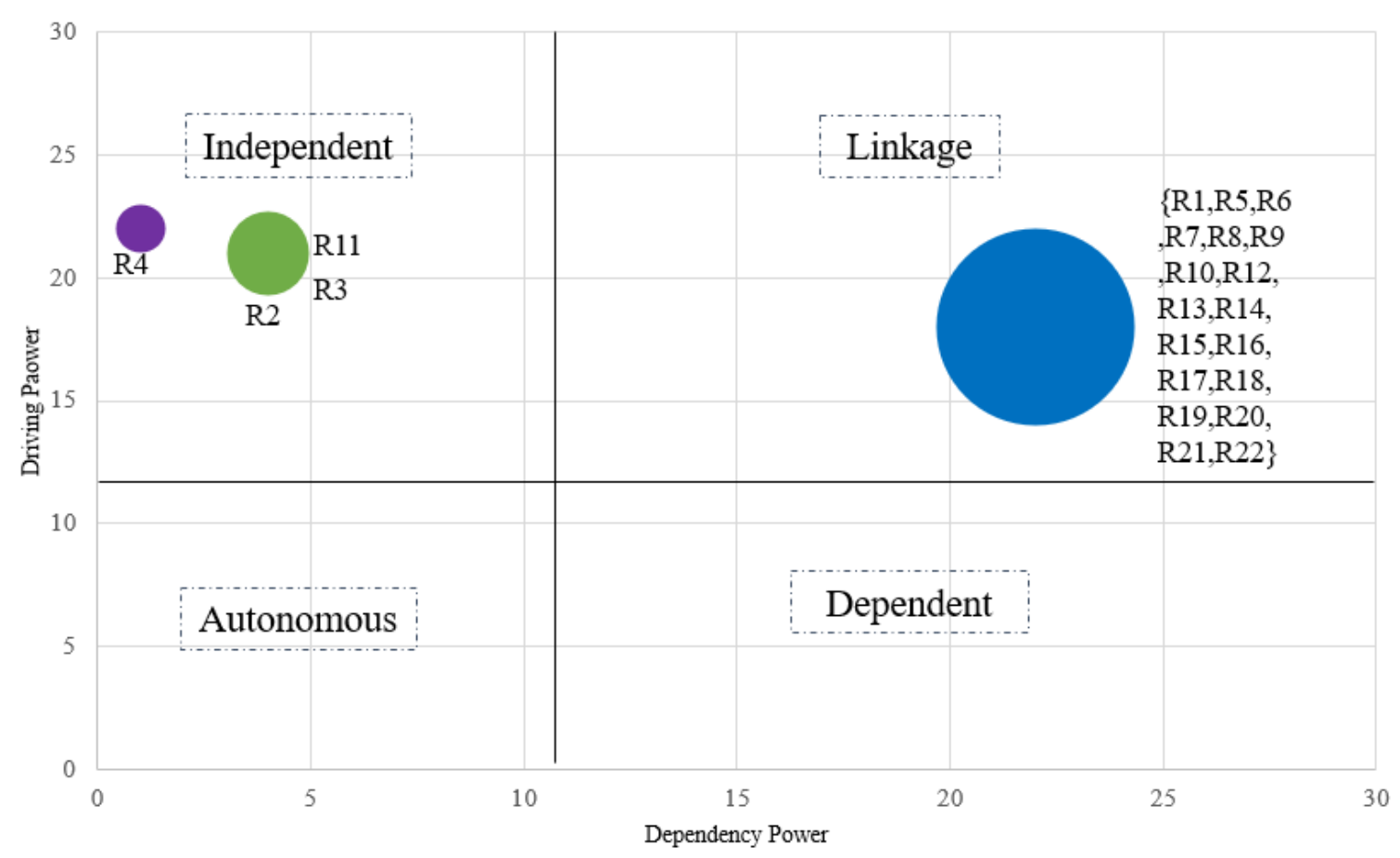

Figure 5. MICMAC Analysis of risk factors.

The results from the MICMAC present a curious relation to the hierarchical ISM diagram in Figure 4. Risk factors in levels I and II belong to the independent. This interprets that force majeure, government or political instability, weak regulatory framework and monitoring, and legal and regulatory changes risk factors directly or indirectly drive the occurrence of the other risk factors. Interestingly, the remaining risk factors also in level III of the hierarchical structure fall in the linkage quadrant. The linkage further implies that those risk factors demonstrate feedback behaviour in the system. The results from the MICMAC analysis further buttresses the ISM-CLD approach adopted in this study such that the feedbacks are explicitly assessed and interpreted using the CLD. Thus, additional interpretation of the relationship behaviour of the risk factors is collectively assessed with much focus on the risk factors in the level III and Linkage quadrant.

\subsubsection{Causal Loop Diagram}

Notwithstanding the graphical communication of the cause-and-effect relationships amid risk factors obtained in the CLDs, it enables the development of measures and mitigating strategies that can improve the system given the feedback and change behaviours of the risk factors. The focal point of the CLD is to divulge and understand the feedback and causal actions of the pertinent risks associated with Sino-Africa public infrastructure dealings to enable optimal and fair allocation. More so, the structural analysis and results from the ISM and MICMAC evaluation instigated the existence of dynamic relationships and feedback justifying further probing, modelling, and interpretation with the CLD. The CLD further interprets the relationships and best determines how and what mitigating strategies can be introduced in the system to ensure successful project implementation. The Vensim PLE was used in the design and analysis of the system. Figure 6 illustrates the loop diagram of the interactions in the system. The ISM analysis established the rela- 
tionship density amongst risk factors (see final RM matrix), hence the CLD emphasises risk factors with the crucial feedback attributes. The arrows in the diagram illustrate that the risk at the tail influences the risk at the arrowhead. The regulation in CLDs describes a self-reinforcing system or a self-balancing system determined by the arrow directions and the $(+/-)$ symbols on the arrowhead. The reinforcing system depicts a system that is in growth or increasing effect due to equivalent influences among system elements. In a self-balancing system, there is an element that controls or puts a limitation on growth [75].

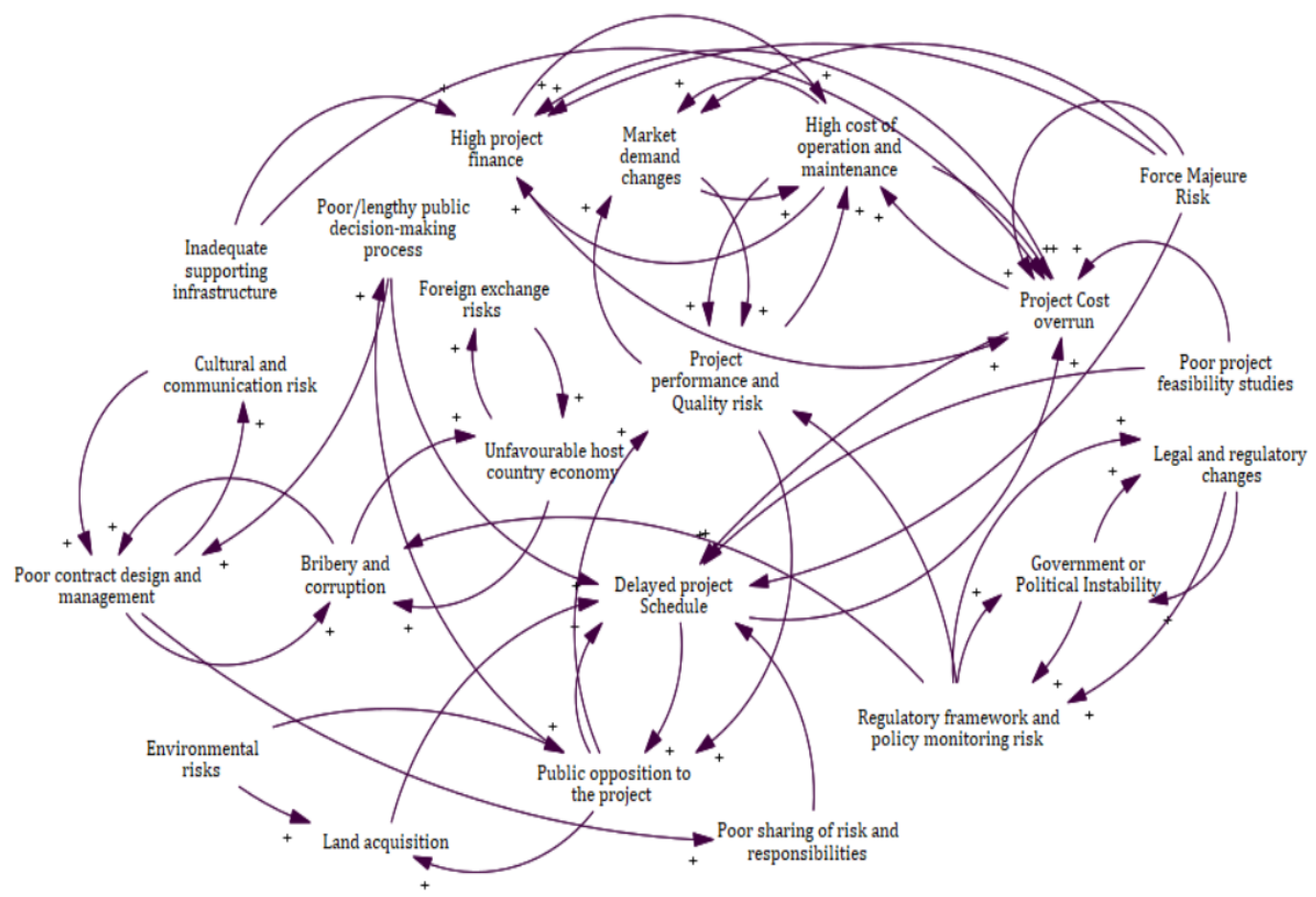

Figure 6. Causal Loop Diagram of Risk factors.

\subsubsection{Causal Path and Loop Interpretation}

The expert evaluation of risk factors pertinent in the delivery of public infrastructure in Sino-Africa dealings summarised negative risks which formed the basis of the systemic analysis. The results in Figure 6 show a self-reinforcing system as the risks within the system reveal increasing influences with no element of control or limitation. This is demonstrated with positive cause and effect relationships among risk factors. The reinforcing activities in the system show that the occurrence of one risk will increase the occurrence of the other where there are no risk factors whose occurrence reduces the occurrence of another. For instance, an increase in the occurrence of market demand changes (see delineation in Table 3) can cause an increase in the occurrence of project performance and quality risk (also see Table 3), and also an increase in project performance and quality risk can cause an increase in the market demand changes.

The risk causal path analysis from the CLD focused on Level I and the Linkage risks from the ISM and MICMAC analysis respectively. This is to provide a further appreciation of the causal relationships amongst those risk factors. Additionally, this study is geared towards risk efficient assessment for fair risk allocation to promote project success. Therefore, causal paths for risk factors associated with the conventional project success criteria (time, cost, and quality) in the CLD are construed. Risk R15, project cost overrun; $R 22$, delayed project schedule; and $R 12$, project performance and quality risk, were selected and expanded under three scenarios.

Scenario 1-Project cost overrun. The system indicates that the delayed project schedule, force majeure, high cost of operation and maintenance, poor project feasibility studies, 
inadequate supporting infrastructure, and high project finance can influence the occurrence of cost overrun. These risk factors are also linked to other risk factors shown in Figure 7.

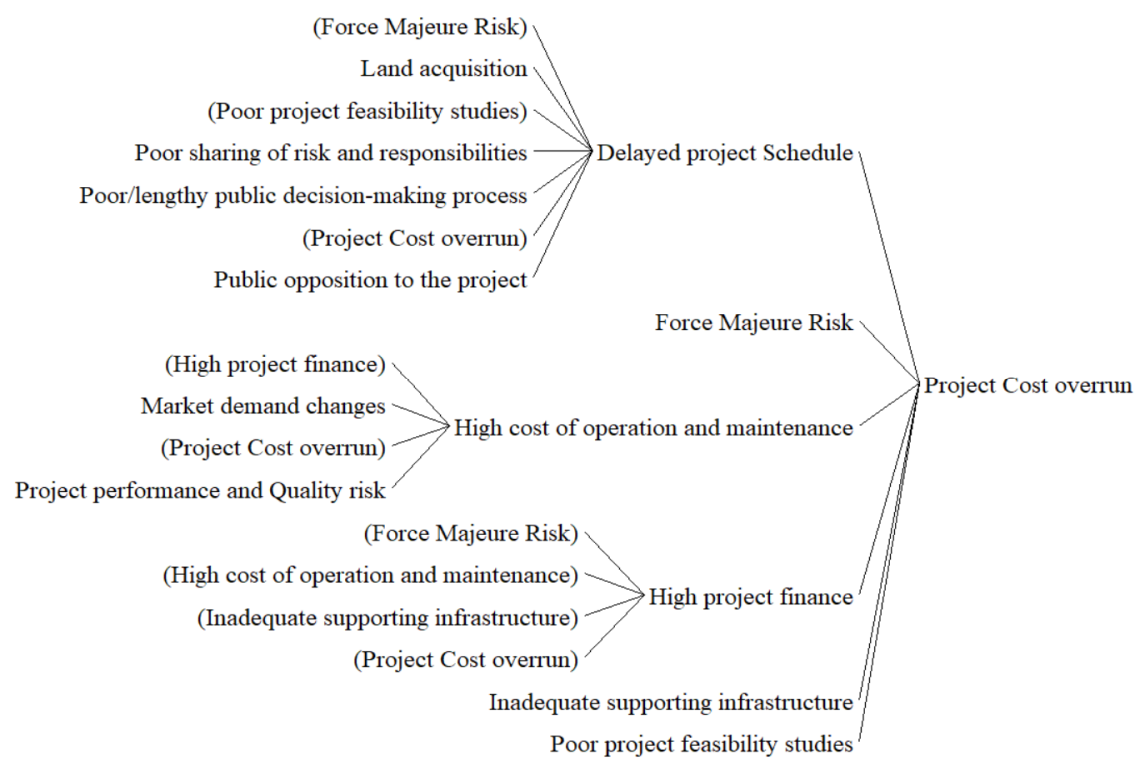

Figure 7. Scenario 1: Project cost overrun risk path.

Scenario 2-Delayed project schedule. Considering the time success criteria, the risk factors that can cause a delay in project schedule include force majeure, land acquisition, poor project feasibility studies, poor sharing of risk and responsibilities, poor/lengthy public decision process, project cost overrun, and public opposition to the project. Other linking risk factors are captured in Figure 8.

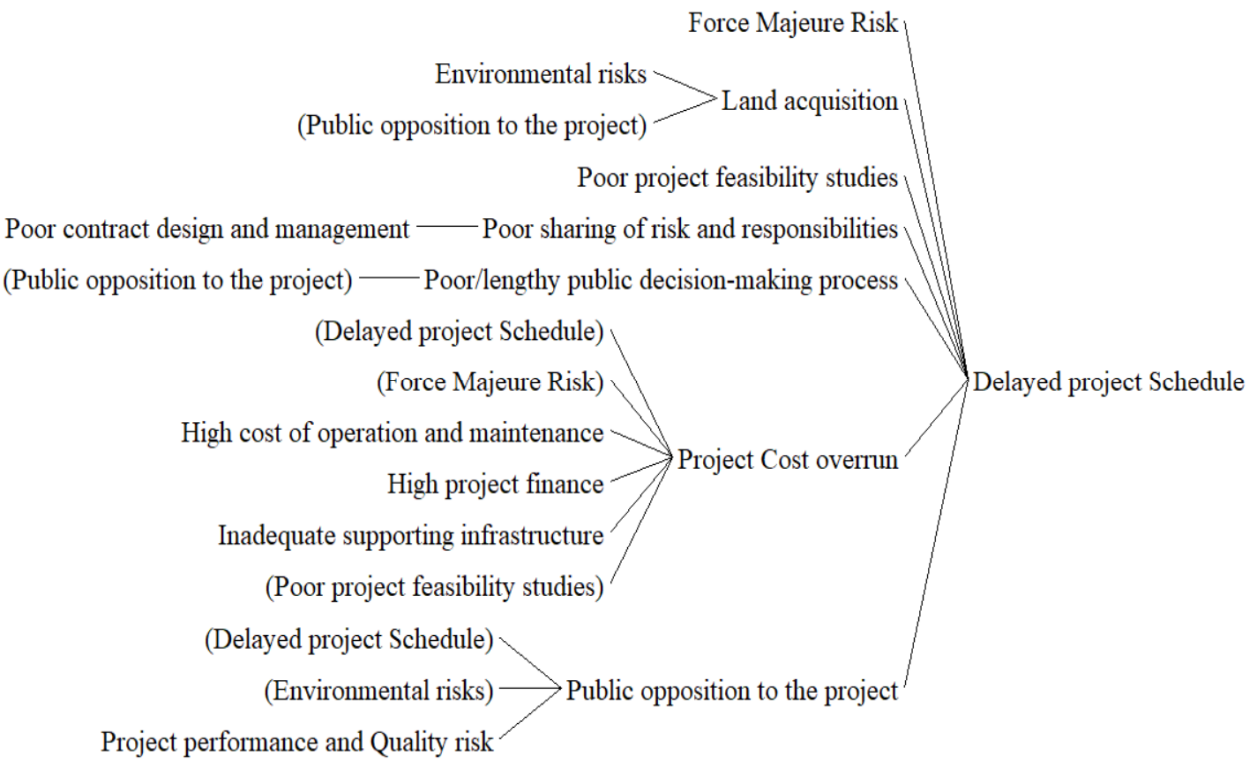

Figure 8. Scenario 2: Delayed project schedule risk path.

Scenario 3-Project performance and quality risk. The causal tree from the system indicates that the high cost of operation and maintenance, changes in market demand, public opposition, and the weak regulatory framework and policy monitoring risk factors take a toll on the performance and quality risk. Further, into scenario three shown in Figure 9, force majeure and environmental risk also play influential actions on the quality risk. 


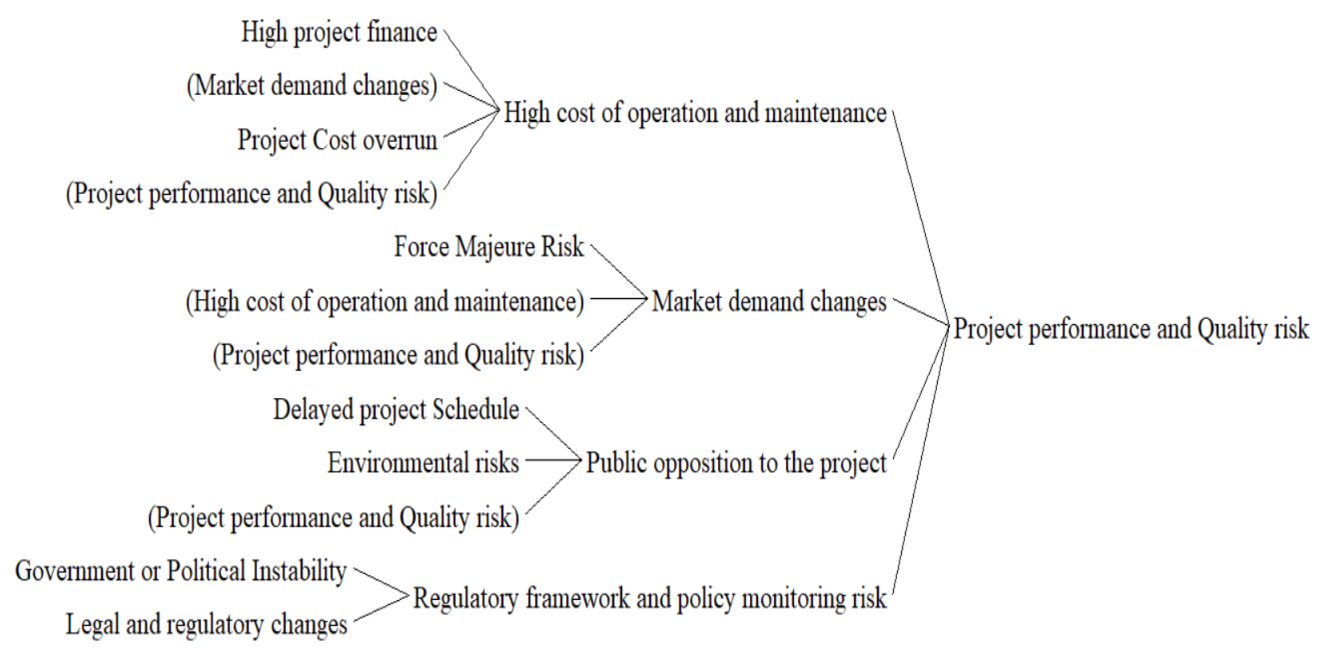

Figure 9. Scenario 3: Project performance and quality risk path.

The subtleties of force majeure (R4)R2, R3, and R11 (all associated with the governance structure and stability of the host country) are evident in all three scenarios. Furthermore, the delayed project schedule cost overrun as well as performance and quality risk factors are seen in a dynamic behaviour as they affect themselves and also influence other factors that, in turn, influence their occurrence in the system.

\section{Discussion}

Sino-Africa TPPP for public infrastructure provision is judged as one of the effective routes to bridging the infrastructure gap in Africa and it is anticipated that these dealings are likely to increase. This is especially with the inception of the Belt and Road Initiative (BRI), which has aided in providing infrastructure in different countries in Africa including, Djibouti, Ethiopia, Ghana, Nigeria, Tanzania, amongst others. In the life cycle development of public infrastructure, uncertainties and complexities are inevitable [76]; hence, assessment of risks is essential to the success of Sino-Africa TPPPs [77]. This study proves the realistic dynamics of the risk relationship causalities and structure in Sino-Africa TPPPs that require critical consideration during development. The sublevel risk determined in this study translates that most risk factors pertinent to Sino-Africa TPPPs are affected by other risks as much as they influence others (i.e., feedback behaviour) and the independent risk factors are force majeure and governance structure and stability related.

\subsection{Force Majeure Risks}

These are events that affect the project actors from normally performing their duties from no fault of either actor. The hierarchical level of force majeure risk in this study reveals that it can directly or indirectly influence the occurrence of all the other risks. Force majeure risk events include earthquakes, floods, fire, plague, and other natural disasters. The author of [77], in his evaluation of Sino-Africa TPPPs, indicated that this force majeure risk is usually shared among private and public parties; however, to the extent any such risks are capable of being insured against, they are often excluded from consideration. This means that project actors barely place focus on it due to the extent of uncertainty. However, recent happenings have challenged project actors to place measures to the best of their ability, to secure the project from suffering the occurrence of force majeure risk. The COVID-19 pandemic is a true indication of the impact of force majeure. The COVID-19 pandemic has caused an awakening in public-private partnership implementation and experts have begun probing efficient methods to maintain operations and control its effects on the project life cycle development [78-80]. This study re-echoes the causal dynamics of force majeure risk, which require more careful consideration in infrastructure delivery. 


\subsection{Governance Structures and Stability Related Risks}

The next level of risks in Sino-Africa TPPPs is associated with the governance structure and stability of the host country in Africa. They include the government or political instability, legal and regulatory changes and weak regulatory framework, and policy monitoring risk. Usually, in the Sino-African setting, the host county's financial system is not of much influence as compared to risk factors associated with governance structures and stability. This is attributable to the nature of partnership agreements ranging from infrastructure for mineral resources [81], inter-governmental concessionary loans and/or the EPC + F model (engineering procurement and construction plus finance) mostly adopted [77]. The weakness and inefficiencies in the legal and regulatory frameworks of some African countries have affected the early completion and success of infrastructure development in Sino-Africa TPPPs $[7,82]$. Political instability sometimes brings about changing priorities in governance which affect the smooth continuity of projects [83]. The study by [84] also stressed that poor leadership governance which lacks effective accountability or checks and balances poses negative risks to public infrastructure development in the region. Therefore, African governments must reform and ensure a tranquil and desirable governance environment with working structures to attract more partnerships to close the infrastructure gap [35]. Results from this study concur with the findings of [41] in risk assessment of TPPPs. It divulged that the risk factors regarding the host country environment must be prioritised by the investors and the entire project team.

\subsection{Project Cost, Schedule, and Performance Quality-Related Risks}

Successful implementation of public infrastructure given the Sino-African approach is measurable by the achievement of the cost, time, and quality dimensions [85]. Knowledge of the dynamics and occurrence of various risk events at different stages of project implementation equips project actors to primarily prevent or reduce the negative effect on time, cost, and quality. Studies in Sino-Africa infrastructure partnerships outline several reasons for the failure or challenging project implementation. Some of these include communication and cultural differences, bribery and corruption, conflict of interest, and lack of trust and transparency $[86,87]$. These risks affect negotiation and cause lengthy decision making and eventually the development and management of conditions of contract [88]. Poor contractual management has resulted in the failure of projects in meeting cost, time, and quality preferences. Furthermore, Ref. [89] asserted that delay in land acquisition and inadequate supporting infrastructure or facilities in West Africa affected the smooth implementation of infrastructure through Sino-Africa TPPPs. This affects the cost, schedule, and performance quality of the project and in some cases has sparked public opposition and rejection of the facility. $[86,90]$. The development of sound economic fundamentals in receiving countries creates a good and less risky investment environment as they limit the likelihood of high financing and cost overruns during project implementation [34,91]. TPPP project risks in infrastructure provision due to complexity and multistakeholder nature are critical and interactive throughout the various stages of implementation and the effective assessment and control of risks systemically will improve project cost, schedule, quality, and overall success of the project.

\section{Conclusions}

Most African governments through engagements with Chinese state-owned corporations have procured public infrastructure such as roads, railways, dams, and water treatment plants, among others. These partnerships are established on the sharing of project risks between the African government or contracting authority and the Chinese corporations. Studies have shown that infrastructure investments in Africa are heavily susceptible to negative risks due to the dynamic behaviour of the socio-economic and political environment in the region. Considering the uniqueness of Sino-Africa TPPP, and the risky nature of infrastructure implementation in Africa, the study considers the identification and assessment of pertinent risks in project delivery. Most TPPP studies assess risk factors 
focusing on their impact and criticality. However, these risks interact with each other and have feedbacks. Therefore, the commonly adopted traditional mode of assessing risks autonomously limits efficiency in the allocation and development of treatment and control strategies. Palpably, the assessment of risk exclusively by criticality may not warrant a better appreciation of the nature of the risks, and project actors tend to channel their focus on the critical and less critical sometimes ignored. This study emphasises that although some risks may not be seen as highly critical, they could have an influence on the occurrence or consequences of critical risks and therefore ignoring interrelationships during the assessment is inept. In view of this, the study adopts system thinking in the evaluation of risks whereby their interrelationships are determined and examined through an integrated approach using integrated structural modelling and causal loop diagram (ISM-CLD). The systemic assessment of the risk factors revealed a dense interrelationship, and the ISM iteration process built a three-level hierarchical structure of the Sino-Africa TPPP risks. Force majeure, risk factors associated with the governance structure and stability of the host African country, and all other identified risks are placed as level three, two, and one, respectively. The MICMAC evaluation further established level one risks as linkage risks (i.e., having high driving and dependence powers) and therefore have feedbacks on themselves. The causal loops enabled the assessment of these feedbacks and results showed that risk factors demonstrate a reinforcing systemic structure and can be used as a conceptual framework for developing mitigating strategies to balance the system. The ISM-CLD approach requires expert opinion and therefore poses a qualitative approach to systems thinking. The study was limited to a qualitative perspective through the elicitation of expert opinion; however, a larger number of professionals coupled with more projectbased investigations can be quantitatively assessed. Therefore, the study recommends that other methods that combine quantitative assessment like system dynamics be explored to examine the mitigating strategies adopted. Furthermore, the causal risk paths can be used to develop hypotheses for further quantitative exploration. As a contribution to research and development, this study developed and applied a methodology i.e., ISM-CLD that integrates causal loop and interpretive structural modelling to qualitatively engage experts in probing complexities and interdependencies in risk assessment and this can be adopted in other research fields. Furthermore, the findings provide useful information to TPPP practitioners on the relevance and a way of incorporating systems thinking in the evaluation of project risks. Thus, practitioners can trace the causality paths of projects risks which will improve the effectiveness of allocation and mitigation decisions. The hierarchical structuring of the risks can also enable prioritisation decisions. Lastly, the study proposes that practitioners pay particular attention and keep records of risk occurrences and their causes or triggers during project delivery to inform the application of this method as a guide to the execution of new or future projects.

Author Contributions: Conceptualization, methodology, investigation and writing B.T.B.E.; supervision and reviewing A.P.C.C. All authors have read and agreed to the published version of the manuscript.

Funding: This research is fully funded by the research Grant Council (RGC) in Hong Kong under the Hong Kong Ph.D. fellowship scheme.

Informed Consent Statement: Not applicable.

Data Availability Statement: Available upon request from corresponding author.

Conflicts of Interest: The authors declare no conflict of interest.

\section{Appendix A}

def transitiveClosure (initial_reachability_matrix):

result $={ }^{\prime \prime \prime}$

length $=$ len(matrix)

for $k$ in range( 0 , length): 


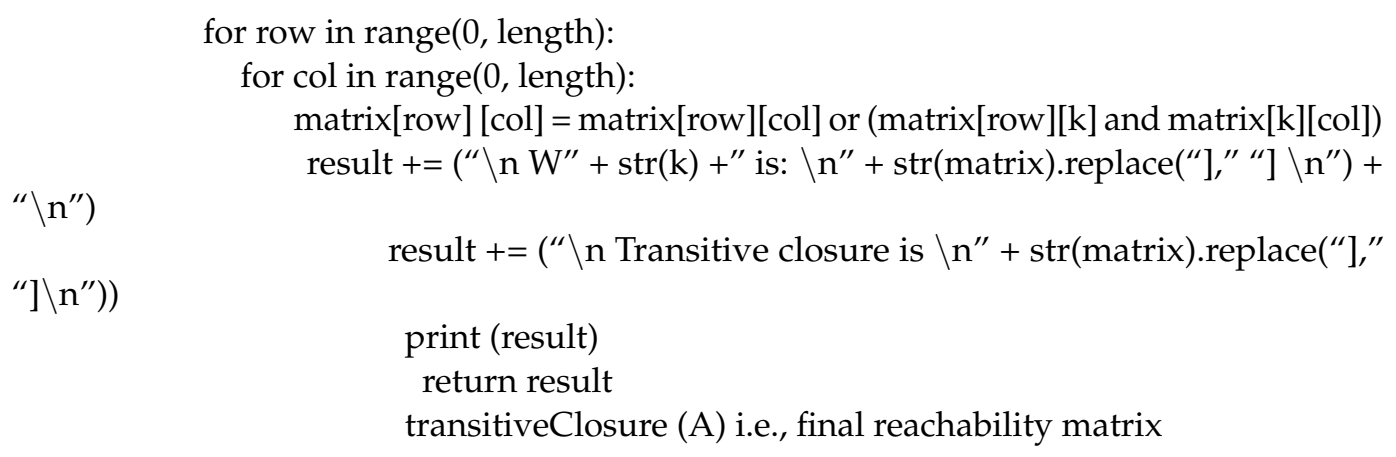

\section{References}

1. Sy, A.N.; Gutman, J. Financing African Infrastructure: Can the World Deliver? Global Economy and Development program; Brookings Institution: Washington, DC, USA, 2015.

2. Wan, Y.; Zhang, L.; Xue, C.Q.; Xiao, Y. Djibouti: From a colonial fabrication to the deviation of the "Shekou model". Cities 2020, 97, 102488. [CrossRef]

3. Schäferhoff, M.; Campe, S.; Kaan, C.J.I.S.R. Transnational public-private partnerships in international relations: Making sense of concepts, research frameworks, and results. Int. Stud. Rev. 2009, 11, 451-474. [CrossRef]

4. Gocking, R. Ghana's Bui Dam and the contestation over hydro power in Africa. Afr. Stud. Rev. 2021, 64, 339-362. [CrossRef]

5. Ndzendze, B.; Monyae, D. China's belt and road initiative: Linkages with the African Union's Agenda 2063 in historical perspective. Transnatl. Corp. Rev. 2019, 11, 38-49. [CrossRef]

6. Goodfellow, T.; Huang, Z. Contingent infrastructure and the dilution of 'Chineseness': Reframing roads and rail in Kampala and Addis Ababa. Environ. Plan. A Econ. Space 2021, 53, 655-674. [CrossRef]

7. Alves, A.C. China's 'win-win' cooperation: Unpacking the impact of infrastructure for-resources deals in Africa. S. Afr. J. Int. Aff. 2013, 20, 207-226. [CrossRef]

8. Eshun, B.T.B.; Chan, A.P.; Osei-Kyei, R. Conceptualizing a win-win scenario in public-private partnerships: Evidence from a systematic literature review. Eng. Constr. Archit. Manag. 2020. Available online: https:/ /www.emerald.com/insight/content/ doi/10.1108/ECAM-07-2020-0533/full/html (accessed on 27 September 2021).

9. Bovis, C.H. Risk in public-private partnerships and critical infrastructure. Eur. J. Risk Regul. 2015, 6, 200-207. [CrossRef]

10. Fahad Al-Azemi, K.; Bhamra, R.; Salman, A.F. Risk management framework for build, operate and transfer (BOT) projects in Kuwait. J. Civ. Eng. Manag. 2014, 20, 415-433. [CrossRef]

11. Moini, N. Modeling of risks threatening critical infrastructures: System approach. J. Infrastruct. Syst. 2016, 22, 04015010. [CrossRef]

12. Jin, H.; Liu, S.; Liu, C.; Udawatta, N. Optimizing the concession period of PPP projects for fair allocation of financial risk. Eng. Constr. Archit. Manag. 2019, 26, 2347-2363. [CrossRef]

13. Wang, J.; Yuan, H. System dynamics approach for investigating the risk effects on schedule delay in infrastructure projects. $J$. Manag. Eng. 2017, 33, 04016029. [CrossRef]

14. Babatunde, S.O.; Perera, S.; Adeniyi, O. Identification of critical risk factors in public-private partnership project phases in developing countries A case of Nigeria. Benchmarking-Int. J. 2019, 26, 334-355. [CrossRef]

15. TarrÓSy, I. China's Belt and Road Initiative in Africa, Debt Risk and New Dependency: The Case of Ethiopia. Afr. Stud. Q. 2020, $19,8-28$.

16. Githaiga, N.M.; Burimaso, A.; Wang, B.; Ahmed, S.M. The belt and road initiative: Opportunities and risks for Africa's connectivity. China Q. Int. Strateg. Stud. 2019, 5, 117-141. [CrossRef]

17. Landry, D. The risks and rewards of resource-for-infrastructure deals: Lessons from the Congo's Sicomines agreement. Resour. Policy 2018, 58, 165-174. [CrossRef]

18. Mortazavi, S.; Kheyroddin, A.; Naderpour, H. Risk evaluation and prioritization in bridge construction projects using system dynamics approach. Pract. Period. Struct. Des. Constr. 2020, 25, 04020015. [CrossRef]

19. Elia, G.; Margherita, A.; Secundo, G. Project management canvas: A systems thinking framework to address project complexity. Int. J. Manag. Proj. Bus. 2020, 14, 809-835. [CrossRef]

20. Wu, Z.; Yang, K.; Lai, X.; Antwi-Afari, M.F. A scientometric review of system dynamics applications in construction management research. Sustainability 2020, 12, 7474. [CrossRef]

21. Agnew, S.; Smith, C.; Dargusch, P. Causal loop modelling of residential solar and battery adoption dynamics: A case study of Queensland, Australia. J. Clean. Prod. 2018, 172, 2363-2373. [CrossRef]

22. Boateng, P.; Chen, Z.; Ogunlana, S.; Ikediashi, D. A system dynamics approach to risks description in megaprojects development. Organ. Technol. Manag. Constr. Int. J. 2012, 4, 593-603. [CrossRef]

23. Liu, X.; Zeng, M. Renewable energy investment risk evaluation model based on system dynamics. Renew. Sustain. Energy Rev. 2017, 73, 782-788. [CrossRef] 
24. Li, M.; Li, G.; Huang, Y.; Deng, L. Research on investment risk management of Chinese prefabricated construction projects based on a system dynamics model. Buildings 2017, 7, 83. [CrossRef]

25. Hughes, D.L.; Dwivedi, Y.K.; Rana, N.P.; Simintiras, A.C. Information systems project failure-analysis of causal links using interpretive structural modelling. Prod. Plan. Control. 2016, 27, 1313-1333. [CrossRef]

26. Chauhan, A.S.; Soni, G.; Rathore, A.P.S. Interpretive structural modelling of risk factors in new product development process: Development of an integrated framework. Int. J. Intell. Enterp. 2017, 4, 361-377. [CrossRef]

27. Trivedi, A.; Chauhan, A.; Singh, S.P. Analyzing glacial lake outburst flood triggers for sustainable disaster risk mitigation: An interpretive structural modelling based approach. Manag. Environ. Qual. Int. J. 2021. [CrossRef]

28. Pitchaimuthu, S.; Thakkar, J.J.; Gopal, P.R.C. Modelling of risk factors for defence aircraft industry using interpretive structural modelling, interpretive ranking process and system dynamics. Meas. Bus. Excell. 2019, 23, 217-239. [CrossRef]

29. Etemadinia, H.; Tavakolan, M. Using a hybrid system dynamics and interpretive structural modeling for risk analysis of design phase of the construction projects. Int. J. Constr. Manag. 2021, 21, 93-112. [CrossRef]

30. Kivleniece, I.; Quelin, B.V. Creating and capturing value in public-private ties: A private actor's perspective. Acad. Manag. Rev. 2012, 37, 272-299. [CrossRef]

31. Long, J.; Chen, C. A causal feedback relationship model for critical success factors of PPP projects based on system dynamics. In International Academic Conference on Frontiers in Social Sciences and Management Innovation (IAFSM 2018); Atlantis Press: Paris, France, 2019.

32. Osei-Kyei, R.; Chan, A.P.C. Factors attracting private sector investments in public-private partnerships in developing countries: A survey of international experts. J. Financ. Manag. Prop. Constr. 2017, 22, 92-111. [CrossRef]

33. Begu, L.S.; Vasilescu, M.D.; Stanila, L.; Clodnitchi, R. China-Angola investment model. Sustainability 2018, 10, 2936. [CrossRef]

34. Oyeranti, G.A.; Babatunde, M.A.; Ogunkola, E.O. An analysis of China-Nigeria investment relations. J. Chin. Econ. Foreign Trade Stud. 2011, 4, 183-199. [CrossRef]

35. Cooke, F.L.; Wang, D.; Wang, J. State capitalism in construction: Staffing practices and labour relations of Chinese construction firms in Africa. J. Ind. Relat. 2018, 60, 77-100. [CrossRef]

36. Yu, Y.; Chan, A.P.; Chen, C.; Darko, A. Critical Risk Factors of Transnational Public-Private Partnership Projects: Literature Review. J. Infrastruct. Syst. 2018, 24, 04017042. [CrossRef]

37. Sun, Y. Transnational public-private partnerships as learning facilitators: Global governance of mercury. Glob. Environ. Politics 2017, 17, 21-44. [CrossRef]

38. Yescombe, E.R.; Farquharson, E. Public-Private Partnerships for Infrastructure: Principles of Policy and Finance; ButterworthHeinemann: Oxford, UK, 2018.

39. Alireza, V.; Mohammadreza, Y.; Zin, R.M.; Yahaya, N.; Noor, N.M. An enhanced multi-objective optimization approach for risk allocation in public-private partnership projects: A case study of Malaysia. Can. J. Civ. Eng. 2014, 41, 164-177. [CrossRef]

40. Chou, J.S.; Pramudawardhani, D. Cross-country comparisons of key drivers, critical success factors and risk allocation for public-private partnership projects. Int. J. Proj. Manag. 2015, 33, 1136-1150. [CrossRef]

41. Yu, Y.; Darko, A.; Chan, A.P.; Chen, C.; Bao, F. Evaluation and Ranking of Risk Factors in Transnational Public-Private Partnerships Projects: Case Study Based on the Intuitionistic Fuzzy Analytic Hierarchy Process. J. Infrastruct. Syst. 2018, 24, 04018028. [CrossRef]

42. Ameyaw, E.E.; Chan, A.P. Evaluation and ranking of risk factors in public-private partnership water supply projects in developing countries using fuzzy synthetic evaluation approach. Expert Syst. Appl. 2015, 42, 5102-5116. [CrossRef]

43. Nguyen, D.A.; Garvin, M.J.; Gonzalez, E.E. Risk allocation in US public-private partnership highway project contracts. Eng. Constr. Archit. Manag. 2018, 144. [CrossRef]

44. Abednego, M.P.; Ogunlana, S.O. Good project governance for proper risk allocation in public-private partnerships in Indonesia. Int. J. Project 2006, 24, 622-634. [CrossRef]

45. Rebeiz, K.S. Public-private partnership risk factors in emerging countries: BOOT illustrative case study. J. Manag. Eng. 2012, 28, 421-428. [CrossRef]

46. Choi, J.H.; Chung, J.; Lee, D.J. Risk perception analysis: Participation in China's water PPP market. Int. J. Project Manag. 2010, 28, 580-592. [CrossRef]

47. Ibrahim, A.U.Y.; Minai, M.S. Malaysian public-private partnerships: Risk management in build, lease, maintain and transfer projects. Cogent Bus. Manag. 2018, 5. [CrossRef]

48. Wibowo, A.; Mohamed, S. Risk criticality and allocation in privatised water supply projects in Indonesia. Int. J. Proj. Manag. 2010, 28, 504-513. [CrossRef]

49. Mazher, K.M.; Chan, A.P.; Zahoor, H.; Khan, M.I.; Ameyaw, E.E. Fuzzy Integral-Based Risk-Assessment Approach for PublicPrivate Partnership Infrastructure Projects. J. Constr. Eng. M. 2018, 144. [CrossRef]

50. Almarri, K.; Alzahrani, S.; Boussabaine, H. An evaluation of the impact of risk cost on risk allocation in public private partnership projects. Eng. Constr. Archit. Manag. 2019, 26, 1696-1711. [CrossRef]

51. Ibrahim, A.D.; Price, A.D.F.; Dainty, A.R.J. The analysis and allocation of risks in public-private partnerships in infrastructure projects in Nigeria. J. Financ. Manag. Prop. Constr. 2006, 11, 149-164. [CrossRef]

52. Dziadosz, A.; Rejment, M. Risk analysis in construction project-chosen methods. Procedia Eng. 2015, 122, 258-265. [CrossRef]

53. Williams, T.J.O. Towards realism in network simulation. Omega 1999, 27, 305-314. [CrossRef] 
54. Hu, A.; Li, N.; Li, C.; Huang, S.Q. Essence and classification of risk in view of systematic dynamics. J. Nat. Disasters 2008, 17, 39-43.

55. Pagoni, E.G.; Georgiadis, P. System dynamics approaches to public-private partnerships: A literature review. Syst. Res. Behav. Sci. 2020, 37, 277-291. [CrossRef]

56. Wan, J.; Liu, Y. A system dynamics model for risk analysis during project construction process. Open J. Soc. Sci. 2014, 2, 451-454. [CrossRef]

57. Alasad, R.; Motawa, I. Dynamic demand risk assessment for toll road projects. Constr. Manag. Econ. 2015, 33, 799-817. [CrossRef]

58. Nasirzadeh, F.; Khanzadi, M.; Rezaie, M. Dynamic modeling of the quantitative risk allocation in construction projects. Int. J. Proj. Manag. 2014, 32, 442-451. [CrossRef]

59. Boateng, P.; Chen, Z.; Ogunlana, S.O. A dynamic framework for managing the complexities of risks in megaprojects. Int. J. Technol. Manag. Res. 2016, 1, 1-13. [CrossRef]

60. Reynolds, M.; Holwell, S. Systems Approaches to Managing Change: A Practical Guide; Springer: Berlin/Heidelberg, Germany, 2010.

61. Anderson, V.; Johnson, L. Systems Thinking Basics; Pegasus Communications: Cambridge, MA, USA, 1997.

62. Forrest, J. A Response to paper "Systems Thinking" by D. Cabrera et al.: Additional thoughts on systems thinking. Eval. Program. Plan. 2008, 31, 333-334. [CrossRef]

63. Sohani, N.; Sohani, N. Developing interpretive structural model for quality framework in higher education: Indian context. J. Eng. Sci. Manag. Educ. 2012, 5, 495-501.

64. Janes, F.R. Interpretive structural modelling: A methodology for structuring complex issues. Trans. Inst. Meas. Control. 1988, 10, 145-154. [CrossRef]

65. Thirupathi, R.; Vinodh, S. Application of interpretive structural modelling and structural equation modelling for analysis of sustainable manufacturing factors in Indian automotive component sector. Int. J. Prod. Res. 2016, 54, 6661-6682. [CrossRef]

66. Xu, X.; Zou, P.X. Analysis of factors and their hierarchical relationships influencing building energy performance using interpretive structural modelling (ISM) approach. J. Clean. Prod. 2020, 272, 122650. [CrossRef]

67. Liu, H.; Skibniewski, M.J.; Wang, M. Identification and hierarchical structure of critical success factors for innovation in construction projects: Chinese perspective. J. Civ. Eng. Manag. 2016, 22, 401-416. [CrossRef]

68. Tariq, S.; Zhang, X. Socioeconomic, Macroeconomic, and Sociopolitical Issues in Water PPP Failures. J. Manag. Eng. 2021, 37, 04021047. [CrossRef]

69. Roubík, H.; Mazancová, J.; Rydval, J.; Kvasnička, R. Uncovering the dynamic complexity of the development of small-scale biogas technology through causal loops. Renew. Energy 2020, 149, 235-243. [CrossRef]

70. Xia, B.; Chen, Q.; Walliah, J.; Buys, L.; Skitmore, M.; Susilawati, C. Understanding the dynamic behaviour of the Australian retirement village industry: A causal loop diagram. Int. J. Strateg. Prop. Manag. 2021, 25, 346-355. [CrossRef]

71. Upadhye, N.; Deshmukh, S.; Garg, S. Lean manufacturing system implementation barriers: An interpretive structural modelling approach. Int. J. Lean Enterp. Res. 2016, 2, 46-65. [CrossRef]

72. Iyer, K.C.; Sagheer, M. Hierarchical structuring of PPP risks using interpretative structural modeling. J. Constr. Eng. Manag. 2010, 136, 151-159. [CrossRef]

73. Vaismoradi, M.; Jones, J.; Turunen, H.; Snelgrove, S. Theme Development in Qualitative Content Analysis and Thematic Analysis. J. Nurs. Educ. Pract. 2016, 6. [CrossRef]

74. Saka, A.B.; Chan, D.W. Profound barriers to building information modelling (BIM) adoption in construction small and mediumsized enterprises (SMEs): An interpretive structural modelling approach. Constr. Innov. 2020, 20, 261-284. [CrossRef]

75. Haraldsson, H.V.J.S.D.C. Introduction to Systems and Causal Loop Diagrams; Lund University: Lund, Sweden, 2000.

76. Buurman, J.; Zhang, S.; Babovic, V. Reducing risk through real options in systems design: The case of architecting a maritime domain protection system. Risk Anal. Int. J. 2009, 29, 366-379. [CrossRef]

77. Cuthbert, N. Public Private Partnerships-The new paradigm for Chinese Companies for funding Africa Infrastructure Project? In Proceedings of the China International Contractors Association (CHINCA) Annual Forum Macau 2018, Macau, China, 7 June 2018.

78. Baxter, D.; Casady, C.B. A coronavirus (COVID-19) triage framework for (sub) national public-private partnership (PPP) programs. Sustainability 2020, 12, 5253. [CrossRef]

79. Bolger, J.C.; Kelly, M.E.; Whelan, C.; Doyle, A.; Frizelle, H.; Boyd, W.D.; McEntee, G.P.; Conneely, J.B. Public-private partnership: Strategies for continuing urgent elective operative care during the COVID-19 pandemic. J. Br. Surg. 2020, 107, e320-e321. [CrossRef]

80. Kim, W.; Jung, T.Y.; Roth, S.; Um, W.; Kim, C. Management of the COVID-19 Pandemic in the Republic of Korea from the Perspective of Governance and Public-Private Partnership. Yonsei Med. J. 2021, 62, 777. [CrossRef] [PubMed]

81. Ampwera, M. Infrastructure and Innovation: Emerging Priorities of EU and Chinese Aid in Africa. China Q. Int. Strateg. Stud. 2019, 5, 511-531. [CrossRef]

82. Omoruyi, E.M.M. Examining the importance of the Sino-Africa swap formula in creating backward and forward linkages. Asian J. Comp. Politics 2020. [CrossRef]

83. Otele, O.M. China, region-centric infrastructure drives and regionalism in Africa. S. Afr. J. Int. Aff. 2020, 27, 511-532. [CrossRef]

84. Lisinge, R.T. The Belt and Road Initiative and Africa's regional infrastructure development: Implications and lessons. Transnatl. Corp. Rev. 2020, 12, 329-342. [CrossRef] 
85. Habibi, M.; Kermanshachi, S.; Rouhanizadeh, B. Identifying and measuring engineering, procurement, and construction (EPC) key performance indicators and management strategies. Infrastructures 2019, 4, 14. [CrossRef]

86. Auffray, C.; Fu, X. Chinese MNEs and managerial knowledge transfer in Africa: The case of the construction sector in Ghana. J. Chin. Econ. Bus. Stud. 2015, 13, 285-310. [CrossRef]

87. Anning, L.; Vhumbunu, C.H. Promoting production capacity cooperation and industrialization through energy infrastructure development: The case of Chinaghana partnership. Contemp. Chin. Political Econ. Strateg. Relat. 2018, 4, 1061-1103.

88. Corkin, L. Chinese construction companies in Angola: A local linkages perspective. Resour. Policy 2012, 37, 475-483. [CrossRef]

89. Chen, K.; Xu, S.; Haralambides, H. Determining hub port locations and feeder network designs: The case of China-West Africa trade. Transp. Policy 2020, 86, 9-22. [CrossRef]

90. Farooq, M.S.; Yuan, T.; Zhu, J.; Feroze, N. Kenya and the 21st century maritime silk road: Implications for China-Africa relations. China Q. Int. Strateg. Stud. 2018, 4, 401-418. [CrossRef]

91. Co, C.Y. Chinese contractors in developing countries. Rev. World Econ. 2014, 150, 149-171. [CrossRef] 